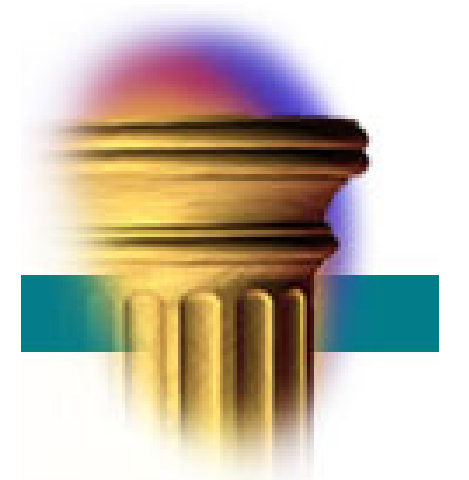

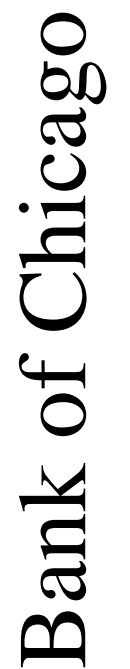

The Effect of Vehicle Fuel Economy Standards on Technology Adoption

Thomas Klier and Joshua Linn

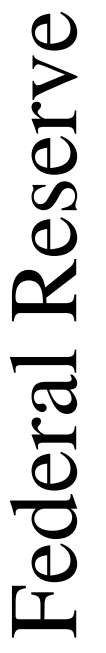

September 2014

WP 2014-22 


\title{
The Effect of Vehicle Fuel Economy Standards on Technology Adoption
}

\author{
Thomas Klier (Federal Reserve Bank of Chicago) \\ Joshua Linn (Resources for the Future) ${ }^{1}$
}

September 2014

\begin{abstract}
$\underline{\text { Abstract }}$
Many countries are tightening passenger vehicle fuel economy standards. The literature on passenger vehicle standards has used structural models to estimate their welfare effects. This paper provides the first empirical evidence on the effects of recently tightened fuel economy standards on technology adoption. Specifically, it investigates changes in the rate and direction of technology adoption, that is, the extent to which technology is used to increase fuel economy at the expense of other vehicle attributes. We find that recent U.S. and European standards have both increased the rate of technology adoption and affected the direction of technology adoption. Producers reduced horsepower and torque compared to a counterfactual in which fuel economy standards remained unchanged. We estimate opportunity costs from reduced horsepower and torque to be of similar magnitude as the gains from fuel savings.
\end{abstract}

JEL codes: L62, Q4, Q5

Keywords: passenger vehicles, U.S. greenhouse gas emissions rate standards, European carbon dioxide emissions rate standards, technology adoption

\footnotetext{
${ }^{1}$ We thank Shanjun Li, Virginia McConnell, seminar participants at the Colorado School of Mines, Cornell University, and the University of Maryland, and conference participants at the International Industrial Organization Conference. Wenfei Du provided excellent research assistance. Linn thanks the MIT Center for Energy and Environmental Policy Research and the Swedish Energy Agency for supporting this research.
} 


\section{Introduction}

Due to concerns about global warming and energy security, a number of countries have recently adopted policies to substantially increase the average fuel economy of new passenger vehicles. The current U.S. Corporate Average Fuel Economy (CAFE) standards, to be met by 2016, are about 40 percent higher than 10 years prior. New standards, extending to 2025, may increase fuel economy of new vehicles sold in the United States by an additional 50 percent. European standards for carbon dioxide $\left(\mathrm{CO}_{2}\right)$ emissions rates (which are inversely related to fuel economy) are scheduled to tighten by about 30 percent between 2012 and 2020. In addition, many other major countries, representing developed economies, such as Japan and Canada, as well as developing countries, such as Mexico and China, have put in place similar policies.

The growing literature on fuel economy standards has used structural models of the new vehicles market to characterize the welfare effects of such standards. ${ }^{2}$ Following standard microeconomic theory, these models allow for the possibility that manufacturers raise prices on vehicles with low fuel economy and reduce prices on vehicles with high fuel economy in order to meet standards in the short term (Green 1991; Goldberg 1998). Several models, such as in Austin and Dinan (2005), also include a longer-term perspective by allowing for the adoption of fuelsaving technology. A number of recent studies include a third margin along which manufacturers can respond to standards; it consists in trading off fuel economy for other vehicle characteristics such as horsepower (e.g., Whitefoot et al. 2011; Knittel 2011; Klier and Linn 2012; Whitefoot and Skerlos 2012). Thus, the literature suggests that manufacturers respond to tightened fuel economy standards by adjusting vehicle prices, adopting fuel-saving technology, and trading off fuel economy for other vehicle characteristics.

The broader literature on technology adoption and innovation provides a different perspective on fuel economy standards. It suggests that tightened standards result in manufacturers innovating and adopting technology more quickly, in addition to trading off fuel economy for other vehicle characteristics. The literature has demonstrated that profit and market forces can affect product characteristics. For example, Newell et al. (1999) show that

\footnotetext{
${ }^{2}$ Analysis by the U.S. regulatory agencies-the U.S. Environmental Protection Agency (EPA) and the U.S. Department of Transportation National Highway Traffic Safety Administration (NHTSA) - tends to be more favorable to fuel economy standards than the economics literature (see e.g. Jacobsen 2012). Although there are many differences between the analysis of the regulatory agencies and the studies in the economics literature, assumptions about technology costs likely play an important role in explaining the differing conclusions.
} 
characteristics of air conditioners respond to regulatory and market pressures. Popp (2002) and Linn (2008) find that the rates of innovation and technology adoption in the manufacturing sector respond to energy prices. ${ }^{3}$ However, although standard micro theory suggests that fuel economy standards affect the rate of technology adoption and cause manufacturers to trade off fuel economy for other characteristics, neither the CAFE literature nor the technology literature has tested these predictions.

Our paper provides the first such evidence for the new vehicles market. We analyze four recent changes in standards in the United States and Europe and examine manufacturers' response to those changes. The United States tightened fuel economy standards for light trucks in 2003 and for both cars and light trucks between 2007 and 2009. Europe adopted mandatory $\mathrm{CO}_{2}$ emissions rate standards between 2007 and 2009, replacing a voluntary standard, which, incidentally, manufacturers did not meet (Klier and Linn, forthcoming). Departing from most of the structural CAFE literature, but in the spirit of the technology literature, we take a reduced form approach and ask whether recent standards have increased the rate at which manufactures adopt technology. In light of the recent focus in the CAFE literature on tradeoffs between fuel economy and other vehicle characteristics, we also ask whether this margin is important in practice.

The empirical strategy consists of two stages. The major empirical objective in the first stage is to distinguish between a) technology adoption that trades off fuel economy for other vehicle characteristics and b) technology adoption that raises fuel economy without sacrificing the other characteristics. The approach builds on Linn (2008), Knittel (2011), and Klier and Linn (2012). We begin by defining a frontier that corresponds to a vehicle's minimum fuel consumption rate (the reciprocal of fuel economy), given its horsepower, weight and other characteristics. Movement along the frontier represents tradeoffs between characteristics that the manufacturer can make without redesigning the vehicle; we refer to such changes as medium-term tradeoffs. To simplify our analysis we assume that the magnitude of the tradeoffs along the frontier-for example, the percent change in horsepower needed to increase fuel economy by 1 percent—does not vary across vehicles or over time. This assumption allows us to use a simple linear regression

\footnotetext{
3 There is a related literature on consumer valuation of product characteristics and product design (e.g., Mazzeo et al. 2013 and Sweeting forthcoming).
} 
technique that simultaneously estimates the shape of the frontier and its position at each point in time.

We use detailed engine and vehicle characteristics data to estimate technical tradeoffs among fuel economy and other vehicle characteristics. We estimate these tradeoffs separately for the U.S. and European vehicle markets. Previously, Knittel (2011) and Klier and Linn (2012) estimated tradeoffs using cross-sectional and time series variation in vehicle characteristics. We extend their analyses by matching engine data to vehicle model production data. That allows us to distinguish between medium-run and long-run tradeoffs among fuel economy, weight, and power. We make this distinction because understanding engine design cycles, which typically last 8-10 years, is important for assessing how easily manufacturers can meet a particular standard at a given time. Technological tradeoffs between fuel economy and other characteristics across design cycles may be different from tradeoffs within design cycles. Failing to distinguish between within-cycle (medium-run) and cross-cycle (long-run) tradeoffs can overstate manufacturers' ability to trade off weight and power for fuel economy in the medium run and understate this ability in the long run. We further improve on the literature by estimating separate frontiers by engine, model, and model-year, rather than by just model-year, as in Knittel (2011).

In the second stage, we use the estimated frontiers to examine whether recent standards have affected the rate or direction of technology adoption, where a change in direction refers to movement along the frontier. ${ }^{4}$ Knittel (2011) and Klier and Linn (2012) provide suggestive evidence that the introduction of the CAFE standards in 1978 affected both the rate and direction of technology adoption. Knittel (2011) finds that the rate of adoption was faster in the early 1980s than in later years but does not control for other factors, such as import competition. Klier and Linn (2012) show that falling weight and horsepower explains about half of the overall fuel economy increase in the early 1980s (see Figure 1), but they do not establish a causal connection between fuel economy standards and weight and horsepower.

We identify the effect of standards on the rate and direction of technology adoption using the variation in regulatory stringency across manufacturers and over time. This variation allows us to

\footnotetext{
${ }^{4}$ An increase in the rate of technology adoption raises fuel economy without sacrificing other vehicle characteristics.
} 
control for other factors that affect technology, the two most important of which are the rising gasoline prices in the mid- to late 2000s and the timing of the subsequent recession. ${ }^{5}$

Regarding the four cases of tightening standards, we find that the change in U.S. light truck standards in 2003 and 2007 affected both the rate and direction of technology adoption. The 2007 U.S. car standards affected the rate of technology adoption, although not as much as for light trucks; there is mixed evidence whether the 2007 car standards also affected the direction of technology adoption. The European standards affected the rate of adoption and also had a small, but statistically significant, effect on the direction of technology adoption.

These results provide evidence that the standards can affect both the rate and direction of technology adoption. To assess the economic significance of these effects, we perform simulations that yield rough estimates of the value of changes in fuel economy and other characteristics caused by tightened standards. To do that, we define the opportunity costs of the standards as the consumer willingness to pay for changes in vehicle characteristics other than fuel economy. We estimate the opportunity costs of a hypothetical 10 percent increase in fuel economy for both the United States and Europe. The estimated opportunity costs for U.S. light trucks are similar in magnitude to the value of the improved fuel economy. For U.S. and European cars, we find that opportunity costs are smaller than for light trucks. Thus, structural models used to estimate welfare costs of tightened standards that do not include tradeoffs between vehicle characteristics miss a quantitatively important aspect of the welfare costs.

Our paper is most closely related to Knittel (2011). However, our paper differs along several dimensions by (a) improving on the frontier estimation; (b) estimating the effects of recent standards on the rate and direction of technology adoption; and (c) providing estimates of the costs to consumers of the changes in vehicle characteristics other than fuel economy.

\section{Data}

The U.S. data come from several sources. Vehicle sales are from Wards Auto Infobank. Monthly sales data are aggregated to the model by model-year, where a model-year begins in

\footnotetext{
${ }^{5}$ The recession affected brand market shares in the United States and Europe and dramatically reduced manufacturer profits ( $\mathrm{Li}$ et al. 2013; Busse et al. 2013). Both factors would likely encourage consumers to purchase less expensive vehicles with higher fuel economy, which could affect manufacturers' technology choices. In the results section we report several pieces of evidence that suggest that our identification strategy can control for these factors.
} 
September of the previous calendar year and ends in August of the current year. The vehicle sales data are measured at the vehicle model level. The sales data distinguish different power sources, such as gasoline/diesel, hybrid, and electric. We merged to the sales data other engine characteristics — such as engine displacement, number of cylinders, horsepower, torque, and fuel economy-from Wards annual yearbooks. Those characteristics were measured at the model version level, for example distinguishing versions of the Honda Accord that have 4 and 6 cylinders. The characteristics data distinguish diesel fuel from gasoline versions.

Finally, we merge to the Wards data additional engine data by vehicle model, fuel type, and number of cylinders. These engine data distinguish three levels of engine aggregation: an engine platform combines related engine programs, each of which in turn may consist of multiple engine models. The data, which originated with IHS Global Insight, allow us to determine when a vehicle is sold with a redesigned engine model and when an engine program is first introduced in a vehicle. ${ }^{6}$

Table 1 provides some summary statistics for the U.S. data for the years 2005 and 2010. The table shows unweighted averages across model versions. There are more than 1,300 observations per year. Between 2005 and 2010, fuel economy increased 6 percent, weight increased 5 percent, and horsepower increased 13 percent. Panel A of Figure 1 shows the trends over the entire sample period, 2000-2012. Horsepower and weight increased steadily in the first half of the sample and then leveled off (more so for weight than horsepower, which resumed growth in 2009), whereas fuel economy was constant in the first half and then increased; these patterns foreshadow the results in Section 4.

The European data were obtained from R.L. Polk and cover the years 2005-2010. The data include all new cars sold in Sweden and the countries with the eight largest markets in Europe: Austria, Belgium, France, Germany, Italy, the Netherlands, Spain, and the United Kingdom. Observations are by country, year, and model version, where a version denotes a unique model name, model trim, number of doors, engine displacement, horsepower, transmission type (manual or automatic), and fuel type (gasoline or diesel fuel). We pool data across European

\footnotetext{
6 The production data available to us have worldwide coverage for 2000-2007 but only cover North America for 2008-2012. This introduces some measurement error in identifying redesign years for engines that are produced only outside North America but are sold in the United States. On average, about 25 percent of vehicles sold in the United States have engines produced outside North America. Restricting the sample to models with engines produced within North America does not appreciably affect the estimation results; this suggests that any measurement error in the redesign variable does not significantly bias the estimates.
} 
countries so that the final data set contains about 47,000 observations per year. Thus, a model version in the European data is much more disaggregated than in the U.S. data. A European model-year corresponds to a calendar year (Klier and Linn 2013).

Table 1 reports summary statistics for the European data for comparison with the U.S. data. Fuel economy is much lower and horsepower is much higher in the United States than in Europe. The fuel consumption rate (measured in gallons per 100 miles) is the reciprocal of fuel economy, and is much lower in Europe than the United States. The reported weight is larger in Europe, but that is because the European data include the gross vehicle weight, and the U.S. data include the curb weight (gross vehicle weight includes the weight of passengers and cargo, which curb weight excludes). The table also shows that fuel economy increased nearly twice as much (in percentage terms) in Europe as in the United States, whereas increases in weight and horsepower were about the same. Panel B of Figure 1 shows that horsepower, weight, and fuel economy increased in the first half of the sample, but in the second half fuel economy increased more quickly while weight and horsepower were flat overall.

\section{Estimating the Frontier: Technical Tradeoffs among Vehicle Characteristics}

\subsection{Empirical Strategy}

In this section we estimate technology frontiers for the United States and Europe. Because the United States has historically regulated the harmonic mean of fuel economy and Europe regulates the $\mathrm{CO}_{2}$ emissions rate, we estimate a fuel consumption frontier for the United States and an emissions rate frontier for Europe. ${ }^{7}$

Before defining the frontier, we briefly summarize the typical vehicle design process. Engines are redesigned every 7-10 years and vehicle models are redesigned every 4-6 years. During an engine or model redesign, the manufacturer can implement large changes. For example, the manufacturer could add technologies to the engine such as cylinder deactivation, which allows an engine with 6 or 8 cylinders to effectively use 3 or 4 cylinders when the engine is not under a heavy load. Similarly, during a model redesign, the manufacturer could trade off a

\footnotetext{
7 The harmonic mean is computed using the reciprocal of fuel economy-i.e., the fuel consumption rate. Thus, using the fuel consumption rate, rather than fuel economy, is consistent with the form of the U.S. standards. Using the fuel consumption rate also fosters comparability with the European analysis, because the fuel consumption rate is proportional to the $\mathrm{CO}_{2}$ emissions rate.
} 
sedan's cabin space for trunk space. Between redesigns, only smaller changes are possible such as increasing the number of transmission speeds or re-tuning the engine to increase horsepower.

We focus on the tradeoffs between weight, horsepower and fuel consumption rate that are possible within and across design cycles of both engine and vehicle. We define the frontier as the minimum fuel consumption rate or emissions rate given a particular horsepower and weight, and holding fixed other vehicle characteristics that cannot be altered without a redesign (such as the number of engine cylinders). The curvature of the frontier represents short-run tradeoffs-for example, between the fuel consumption rate and horsepower - that are possible by adopting technology used in other versions of the same vehicle model, without redesigning it. The medium-run shifts of the frontier include technology adoption that is feasible between redesigns and that does not impose the same tradeoffs between characteristics. Shifts of the frontier thus represent technology adoption during redesigns. Note that our definition of the frontier differs from Knittel (2011), where the frontier represents the maximum fuel economy given horsepower, weight, and other characteristics, and holding production costs constant. Instead, we define the frontier based on design cycles because a) we do not observe production costs, which makes it difficult to control for costs in the estimation; and b) we do observe redesigns, which allows us to distinguish between shifts along the frontier before a redesign, and shifts of the frontier across redesigns.

We estimate the shape and position of the frontier using a linear regression equation that is similar to Knittel (2011) and Klier and Linn (2012):

$\ln e_{i t}=\beta_{0}+\beta_{h} \ln \left(h_{i t}\right)+\beta_{w} \ln \left(w_{i t}\right)+r_{i t} \tau_{m t}+X_{i t} \delta+\varepsilon_{i t}$,

where $e_{i t}$ is the fuel consumption rate (for the U.S. analysis) or $\mathrm{CO}_{2}$ emissions rate (for the European analysis) of model version $i$ in model-year $t ; h_{i t}$ and $w_{i t}$ are horsepower and weight; $r_{i t}$ is a dummy equal to one if the model or engine is redesigned in model-year $t ; \tau_{m t}$ is a set of model by model-year interactions; $X_{i t}$ contains a set of vehicle characteristics, including the transmission type, fuel type (gasoline, diesel fuel, or 85 percent ethanol [E85]), and number of engine cylinders; $\varepsilon_{i t}$ is an error term; and $\beta_{0}, \beta_{h}, \beta_{w}$, and $\delta$ are parameters to be estimated.

Equation (1) can be estimated separately for the United States and Europe. For the U.S. analysis, the dependent variable is the log fuel consumption rate; for the European analysis, the dependent variable is the $\log \mathrm{CO}_{2}$ emissions rate. 
The model by model-year interactions, $\tau_{m t}$, represent the average of the dependent variable across different versions of the same vehicle model in a particular model-year. Thus, a decrease in $\tau_{m t}$ between two consecutive years indicates a shift of the frontier away from the origin. A change in the interaction between consecutive years for a particular model is interpreted as the maximum change in the fuel consumption rate if all of the technology adopted between the two years was used to decrease the fuel consumption rate, and all other vehicle characteristics are held fixed. Importantly, because we estimate equation (1) by ordinary least squares (OLS), we interpret the frontier shift as the potential change in the average log fuel consumption rate across all versions of a vehicle model. We estimate equation (1) by OLS to maintain consistency with Knittel (2011) and Klier and Linn (2012).

Versions of a particular model often are sold with different engines. Because engine redesign cycles do not always correspond to vehicle model redesign cycles, it is possible that the frontier shifts by different amounts between two years for versions of the same model. To allow for this possibility, equation (1) includes the triple interactions of the model by model-year interactions with the variable $r_{i t}$. For each version of a vehicle model, we match the set of engine programs sold with that version. The variable $r_{i t}$ is equal to one if the version is sold with an engine program that is redesigned in year $t$. The triple interaction allows for the possibility that the frontier shifts more for versions that are sold with a redesigned engine than for versions sold with an engine that has not been redesigned. Thus, $\tau_{m t}$ captures the average shift of all versions of the same model that are not redesigned, and the triple interaction captures the differential shift for versions sold with redesigned engines. We expect the interactions of redesign, model, and model-year to decrease over time as manufacturers adopt technology that causes the frontier to shift. The hypotheses are analogous for the European analysis, in which the dependent variable is the emissions rate.

The coefficients on weight and horsepower capture the tradeoffs among vehicle fuel consumption/emissions rates, weight, and horsepower across versions of the same model. Because of the model by model-year interactions, the coefficients are interpreted as the possible tradeoffs between these characteristics in a particular year without a redesign. The coefficients are expected to be positive. If the technology frontiers for European and U.S. vehicles have the same curvature, the coefficients in equation (1) would be equal. The variables in $X_{i t}$ control for 
other determinants of the fuel consumption rate or emissions rate that are fixed between redesigns.

In summary, equation (1) has several important features. First, we allow the tradeoffs between fuel consumption/emissions rates and other characteristics to depend on whether an engine has been redesigned. Second, we allow the frontier to shift out by different amounts for each model. Third, and importantly for Section 4, we do not impose assumptions on the effect of the standards on the direction or rate of technology adoption.

\subsection{Estimation Results}

Table 2 shows the estimates of equation (1) for the United States, with column 1 showing results for cars and column 2 for light trucks. We could include horsepower and torque in all regressions, but in practice they are extremely highly correlated with one another. Our regressions for U.S. and European cars use horsepower; our regressions for U.S. light trucks use torque, which, for light trucks, is more highly correlated with the fuel consumption rate than is horsepower.

Fuel consumption rate, horsepower, and weight are in logs, and the reported horsepower and weight coefficients represent elasticities. The regressions include dummy variables for whether the vehicle uses diesel fuel, has a hybrid power train, is a flex-fuel vehicle (capable of using E85), or has a manual transmission; the coefficients on the indicator variables approximately equal the percentage change in fuel consumption rate associated with having these characteristics. Besides the reported variables, regressions include fixed effects for the number of cylinders and doors and interactions of redesign, model, and model-year.

The estimates in column 1 suggest that a 1 percent increase in horsepower increases the log fuel consumption rate by about 0.24 , which is significant at the 1 percent level. The estimate is significantly larger than Klier and Linn (2012) because the latter focuses on within-engine program variation, whereas these estimates reflect both cross-engine and within-engine program variation. The weight coefficient in column 1 is smaller than Klier and Linn (2012) for the same reason. The horsepower and weight coefficients also differ from Knittel (2011), but the sample periods, independent variables, and data sources differ as well.

The diesel fuel coefficient implies that the log fuel consumption rate of diesel fuel cars is about 0.34 lower than gasoline-powered cars. The coefficient on the manual transmission dummy, which is expected to be negative, is in fact positive, but it is quite small and not 
statistically significant. The coefficient on the hybrid power train dummy indicates that the log fuel consumption rate of hybrid cars is about 0.26 lower than comparable gasoline-powered cars.

Compared to cars, the light truck estimate for the torque coefficient is smaller than the horsepower coefficient, and the estimate for the weight coefficient is larger. The light truck and car hybrid coefficients are essentially the same. The coefficient on flex-fuel vehicles is positive, reflecting the lower energy content of E85 compared to gasoline.

Table 3 reports results for Europe, for which the dependent variable is the log emissions rate rather than the log fuel consumption rate. Besides the reported variables, column 1 includes fixed effects for the number of engine cylinders and interactions of redesign, model, and model-year. The European regressions do not include vehicles with hybrid power trains or vehicles that use flex fuel, but column 1 is otherwise comparable to the U.S. car regression.

Because the European regressions include only passenger cars, we compare the European results with the U.S. car results. The magnitudes of the European horsepower and weight coefficients are very similar to those of the U.S. estimates. The European diesel fuel coefficient is smaller than the U.S. coefficient, but this is because diesel fuel has a higher carbon content than gasoline; if we use fuel consumption rate rather than the emissions rate as the independent variable for the European regressions, the magnitude of the European diesel fuel coefficient is very similar to that of the U.S. coefficient.

A model trim is defined as a unique model name, body type, number of doors, driven wheels, and trim level; different model trims may have different engine models. The greater disaggregation of the European data allows us to estimate a separate frontier position for each model trim and year. For consistency with the U.S. analysis, we focus below on the estimates using redesign by model and model-year interactions, but column 2 of Table 3 reports the redesign by model trim and year results for comparison. The coefficient estimates are quite similar in columns 1 and 2 of Table 3.

\subsection{Robustness}

How confident are we in translating these estimates into a production possibilities frontier? Perhaps the main threat to the identification of possible shifts of the frontier is that the shape of the frontier - as captured by the coefficients on the vehicle characteristics — is assumed to be the same across models as well as over time. If the shape does vary across models or over time, the estimated model by model-year interactions, as well as the triple interactions with the redesign 
variable, would be biased. To address this possibility, we allow for variation in the shape of the frontier in several ways. First, in the main analysis we estimate technology adoption separately for cars and light trucks; the differences between columns 1 and 2 in Table 2 illustrate the importance of doing so. In addition, we investigate a further breakdown of each of those two categories, as they, in turn, encompass vehicles with rather different characteristics. Appendix Table 1 separates the categories further, reporting results by market segment. Cars have three market segments (small, medium, and large/luxury), and light trucks have four segments (crossovers, sport utility vehicles, vans, and pickup trucks). Coefficients are found to vary substantially across segments; for example, weight and horsepower have larger effects on the fuel consumption rate for small cars than for other car segments. Appendix Table 2, which reports separate regressions by European car market segment, shows that the coefficients vary somewhat across segments, but less so than in the U.S. segment-level regressions in Appendix Table 1. Because of this variation in the effect of vehicle characteristics on fuel economy across segments in both the United States and Europe, we continue with the more detailed segment analysis in the second stage of our estimation (see section 4.3).

We also examined whether the tradeoffs between vehicle characteristics along the frontier vary by company or over time. We find some variation in the tradeoffs by company, but allowing for this variation (e.g., by estimating equation (1) by company) does not affect the main results in the next section. Likewise, allowing for changes in the tradeoffs over time (e.g., by interacting the vehicle characteristics in equation (1) with a linear time trend) does not affect the results.

As a final robustness check, following Knittel (2011) we introduced higher-order interactions of the vehicle characteristics to equation (1), such as the interaction between log horsepower and log weight. This partially relaxes the functional form assumptions in equation (1) about the tradeoffs, but it does not affect the second-stage results.

\section{Have Standards Affected the Direction and Rate of Technology Adoption?}

In this section, we use the estimates of equation (1) to investigate whether the recent U.S. and European standards have affected the rate and direction of technology adoption. We first report qualitative aggregate results followed by detailed quantitative cross-sectional results. 


\subsection{Hypotheses for Aggregate Direction and Rate}

We first consider whether the market-wide average rate or direction of technology adoption changed subsequent to the adoption of the new standards. We define the rate of adoption of fuel consumption technology in a specific year as the change between the current and previous years in the market-wide average estimate of $r_{i t} \tau_{m t}$ from equation (1). The change represents the decrease in the average log fuel consumption rate, relative to the previous year, if all of the adopted technology were used to decrease the fuel consumption rate- that is, if manufacturers held fixed other vehicle characteristics. We define the direction of technology adoption as the $\log$ of the ratio of fuel consumption rate to horsepower or weight, respectively (i.e., there are two direction variables).

In the aggregate analysis, we do not attempt to control for potentially confounding factors that affect rate and direction. Instead, we ask simply whether the average rate and direction changed after the standards changed. We consider the U.S. light truck fuel economy standards adopted in 2003, the U.S. car and light truck fuel economy standards adopted in 2007 (and tightened in 2009), and the European $\mathrm{CO}_{2}$ emissions rate standards adopted in 2007 (and finalized in 2009). In each case we ask whether the average rate and direction of technology adoption changed after the standards were adopted.

Note that we look for changes after the standards were adopted rather than when they first had to be met, which is usually two to three years after adoption. Mostly because of the fact that models and engines are redesigned on regular cycles, manufacturers often begin to respond to future standards as soon as they are adopted but before they are implemented. For example, they may introduce vehicles with lower fuel consumption rates prior to the actual increase in the standards, either because the regulator offers credits for pre-standard increases in fuel consumption, or because the manufacturer would otherwise have to wait until several years after the new standards are implemented to redesign the vehicle and reduce fuel consumption rates. Consequently, we start looking for evidence of manufacturer responses once the tighter standards are adopted.

\subsection{Aggregate Results}

Figure 2 shows the aggregate results for the United States and Europe. Vertical lines indicate the adoption years of the standards. The solid black curve is the cumulative frontier shift since 
the year 2000. The curve indicates that the average fuel consumption rate of U.S. cars would have been 12 percent lower in the year 2010 than in 2000 if all vehicle characteristics besides fuel consumption rate had remained at their 2000 levels, in which case the new technology would have entirely been used to reduce fuel consumption rates. The red line is the change in the actual average fuel consumption rate compared to the year 2000. The other lines in the figures are the counterfactual changes in the fuel consumption rate that would have occurred had the corresponding characteristic been held fixed and the frontier not shifted; that is, they represent the fuel consumption rate decrease by moving along the frontier. For example, the horsepower curve indicates that if horsepower had been held fixed from 2000 to 2004, cars would have had about a 3 percent lower fuel consumption rate in 2004 than they actually did. The curve is computed using the actual horsepower change and the horsepower coefficient reported in Table 2. By construction, in the figure the sum of the change in characteristics is equal to the frontier shift.

The figure shows that the average rate and (in most cases) the direction of technology adoption changed soon after the standards changed. Regarding the rate, for U.S. cars (Panel A), the frontier shifted out twice as quickly after 2007 as compared to 2000-2007. For U.S. light trucks (Panel B), the frontier shifted out twice as quickly after 2003 as compared to 2000-2003. The earlier timing for the light trucks is consistent with the fact that the light truck standards tightened before the car standards. For European cars, the frontier also shifted out more quickly after 2007 compared to 2005-2007.

There is also clear evidence that the direction of technology adoption changed as well, particularly for U.S. cars and light trucks. Until about 2007, the average car fuel consumption rate was flat, as manufacturers used the outward shifts of the frontier to improve other characteristics, particularly horsepower. After 2007, on the other hand, the fuel consumption rate began decreasing at about the same rate as the frontier. The pattern is similar for light trucks; the fuel consumption rate was roughly flat until about 2004, after which it began decreasing.

Figure 2 illustrates the market-wide average patterns; Figures 3-5 supplement that with company or brand-level detail. The figures are constructed similarly to Figure 2, except that each 
panel represents a different company (in the United States) or brand (in Europe). ${ }^{8}$ The figures illustrate considerable cross-firm heterogeneity in the rate and direction of technology adoption, but most firms exhibit patterns similar to those shown in Figure 2.

\subsection{Hypotheses for Cross-Sectional Rate and Direction}

Although the aggregate results suggest that the introduction of tighter standards affected both the rate and direction of technology adoption, there may have been confounding influences. For example, gasoline prices began rising in 2003. Given vehicle design lags of three years or more, rising gasoline prices may have affected the rate and direction of adoption as early as 2006 . This subsection presents the approach to control for such potential confounding effects.

The main feature of our identification strategy is that we exploit cross-sectional variation in the stringency of the standards. Although the adoption of each of the four standards (U.S. light trucks in 2003, U.S. cars and light trucks in 2007, and European cars in 2007) affects the entire market, the incentives for changing the direction and rate of technology adoption are likely to vary across manufacturers, depending on how close they are to achieving the new standard. We define the stringency of standards as the difference between a manufacturer's pre-standard fuel consumption or emissions rate and the level of the new standard. A manufacturer with a high fuel consumption rate (and low fuel economy) therefore has a higher value of the stringency variable. ${ }^{9}$ Stringency can vary across manufacturers because of different levels of pre-standard fuel economy or because of differences in the mix of vehicles offered. In both the United States and Europe, standards are administered based on the physical characteristics of vehicles. The U.S. standards for cars and light trucks are calculated based on a vehicle’s footprint, which roughly corresponds to the rectangle defined by its four wheels. According to this approach, larger vehicles are subject to higher fuel consumption rate standards. The European standards are based on weight, such that lighter vehicles are subject to lower emissions rate standards.

\footnotetext{
8 The fuel consumption rate decreased noticeably in 2010 for several manufacturers. Starting in 2010, the fuel consumption rate calculated from Wards data for flex-fuel vehicles corresponds to the fuel consumption rate using 85 percent ethanol rather than gasoline.

${ }^{9}$ We assume that all firms elect to meet the standards. Historically, in the U.S. market, several firms, such as Mercedes, have elected to pay fines instead of meeting the standards. However, beginning in 2011 the EPA and NHTSA jointly regulate greenhouse gas emissions rates and fuel economy, and the EPA fines under the Clean Air Act are orders of magnitude higher than the historical NHTSA noncompliance fines. Hence all firms are expected to comply with the new standards.
} 
Accordingly, in a footprint- based system and similarly for the European weight-based system, manufacturers with larger vehicles are subject to higher fuel consumption rate standards. ${ }^{10}$

Cross-manufacturer variation in stringency enables a differences-in-differences strategy for identifying the effects of standards on the rate and direction of technology adoption. We estimate separate regressions for U.S. cars, U.S. light trucks, and European cars. For the rate of technology adoption, each regression is a variation of the following equation:

$$
r_{i t} \hat{\tau}_{m t}=\gamma_{R} S_{F} \text { Post }_{t}+\text { Seg }_{m} \text { Post }_{t} \ln \left(e_{m}\right)+\theta_{t}+\omega_{m}+v_{i t} .
$$

Observations are by redesign, model, and model-year; that is, there are two observations for a model that was redesigned in a particular year. The dependent variable is the redesign by model and model-year interaction term estimated in equation (1). The variable Post $_{t}$ is a dummy variable equal to one after the standard has been adopted (e.g., post-2007 for Europe), and $S_{F}$ measures stringency by manufacturer, $F$. The variable is the difference between the log of the manufacturer's average fuel consumption or emissions rate in the first year of the sample and the $\log$ of the manufacturer's standard; $\gamma_{R}$ is the coefficient on the interaction of Post $_{t}$ with $S_{F}$. For the U.S. light truck standards, we allow for the possibility that the 2003 and 2007 standards differed from one another in their effects on the direction and rate of adoption and estimate a separate $\gamma_{R}$ for each time period. The term $\operatorname{Seg}_{m}$ Post $_{t} \ln \left(e_{m}\right)$ represents the triple interaction of market segment fixed effects with Post $_{t}$ and the log of the average fuel consumption or emissions rate of the corresponding model in the initial year of the sample. Note that when estimating equation (2), we include all lower-order terms for the triple interaction; we omit these terms in the expression for brevity. Later in the subsection, we discuss how the triple interactions address concerns about gasoline prices and other possibly confounding factors. ${ }^{11}$

\footnotetext{
${ }^{10}$ One might be concerned that provisions in the U.S. and European regulations that equalize marginal compliance costs across firms, such as cross-firm credit trading, would reduce or even eliminate the cross-firm variation in stringency. However, the identification strategy is valid even if marginal compliance costs do not vary across firms. Even in that case, the stringency variable would be proportional tot the regulatory pressure caused by the regulations (Roth 2014).

${ }^{11}$ Rather than estimating equations (1) and (2) separately, we could replace the triple interactions of model by model-year by redesign in equation (1) with the independent variables in equation (2). This would increase the efficiency of the estimates, but the two-stage approach allows for an unobserved component (essentially, a random effect) of the model by model-year by redesign triple interaction.
} 
Equation (2) includes both year fixed effects $\left(\theta_{t}\right)$ and model fixed effects $\left(\omega_{m}\right)$. The year fixed effects control for the average level of the frontier each year and for any unobserved factors that affect the dependent variable proportionately. The vehicle fixed effects control for the average frontier of the corresponding model over the sample. Because of the presence of vehicle fixed effects, a vehicle's frontier shift is measured relative to its average frontier over the sample.

The central hypothesis to be tested is that $\gamma_{R}$ is negative. To illustrate the differences-indifferences interpretation of $\gamma_{R}$, suppose the average frontier for manufacturer A shifts at the same rate as the frontier for manufacturer B prior to the adoption of tighter light truck standards. Assume further that the stringency variable is greater for A than for B, meaning the standard is more stringent for manufacturer $\mathrm{A}$. The coefficient $\gamma_{R}$ is negative if the average frontier for $\mathrm{A}$ shifts more quickly than the average frontier for B after the new light truck standards were adopted (recall that a decrease in the fuel consumption rate corresponds to an increase in fuel economy). Note that the approach cannot distinguish between a case in which the standards caused a one-time frontier shift and a case in which the standards caused the frontier to shift at a faster rate for multiple years. Either case would result in a negative coefficient, but we lack enough years of post-standards data to distinguish them.

There are two main issues that threaten the identification of $\gamma_{R}$. First, unobserved manufacturer or model-level characteristics may be correlated with the stringency-time period variable, $S_{F} *$ Post $_{t}$. The model fixed effects partially mitigate this concern by controlling for time-invariant manufacturer heterogeneity. For example, the estimates are unbiased if the difference between the fuel consumption rate of General Motors' and Toyota's cars that existed prior to 2000 would have persisted after 2000 in the absence of the new standards. This assumption cannot be tested directly, but it is supported by the long period of time, prior to 2005, during which the standards were constant and manufacturers' relative fuel consumption rate was quite stable (Jacobsen 2013). Constructing $S_{F}$ from the vehicle fuel consumption rates at the beginning of the sample further mitigates the first concern because the new standards do not directly affect this variable. We return to this issue in Section 4.5.

The second potential concern is that other factors, such as fuel prices or the onset of the recession, may also affect incentives for technology adoption. The triple interaction in equation (2) controls for such factors to the extent that they are common within a market segment or are 
proportional to the vehicle's initial fuel consumption rate. The underlying assumption is that, after including the triple interaction, our measure of stringency is uncorrelated with the effects of the business cycle and gasoline prices. Section 4.5 documents strong evidence supporting this assumption.

Next, we turn to the direction of technology adoption. The standards could cause manufacturers to shift along the frontier by reducing the fuel consumption rate and reducing horsepower or weight. ${ }^{12}$ We define a set of direction variables, $d i r$, at the vehicle level. The fuel consumption rate-horsepower direction, for example, is the log of the ratio of fuel consumption rate to horsepower. Direction variables for fuel consumption rate-torque and fuel consumption rate-weight are defined similarly. The hypothesis to be tested is that an increase in the stringency of the fuel economy standard causes the direction to shift to reduce the fuel consumption rate and to reduce either torque, horsepower, or weight. We estimate the equation

$$
d i_{i t}=\gamma_{D} S_{F} \text { Post }_{t}+\text { Seg }_{m} \text { Post }_{t} \ln \left(e_{m}\right)+\theta_{t}+\omega_{m}+v_{i t} \text {. }
$$

For the United States we estimate four regressions: two for cars and two for light trucks, where the dependent variables for the car regressions are the horsepower and weight direction variables, and the dependent variables for the light truck regressions are the torque and weight direction variables. For Europe we estimate two regressions, one each for the horsepower and weight direction variables. Observations are by model version and year.

The interpretation of the coefficient $\gamma_{D}$ is similar to that of $\gamma_{R}$. For horsepower, for example, the coefficient is negative if manufacturers with a higher value of $S_{F}$ shift toward a lower fuel consumption rate and away from horsepower, and if this change is greater for manufacturers for which the standard is more stringent. Thus, a negative coefficient suggests that the standards cause manufacturers to change the direction toward a lower fuel consumption rate. For Europe, the coefficient $\gamma_{D}$ is negative for the horsepower regression if manufacturers with a higher initial emissions rate reduce emissions rates at the expense of horsepower more than do other manufacturers.

\footnotetext{
${ }^{12}$ The standards could cause manufacturers to trade fuel consumption for any vehicle characteristics in equation (1). We focus on weight and horsepower (torque) primarily because these two variables are continuous, making it simpler to define the dependent variable in equation (3).
} 


\subsection{Cross-Sectional Results}

For the United States, we allow the effects of the standards to vary across four time periods: 2000-2002, in which light truck and car standards were unchanged; 2003-2006, in which higher light truck standards were first adopted; 2007-2009, in which new car and light truck standards were adopted and the tighter light truck standards, adopted in the previous period, took effect; and 2010-2012 as these standards took effect (subsequent tightening of the standards occurred after the end of the sample period). The last time period allows for the possibility that manufacturers responded more strongly as the tighter standards took effect. The key independent variables are the interactions between stringency and the time period fixed effects. We test whether (a) the direction and rate of technology adoption for light trucks differed between the first time period and the subsequent periods and (b) the direction and rate of adoption for cars differed between the first two periods and the last two periods.

Panel A of Table 4 shows results from estimating equation (3), in which we assess the effect of the standards on the direction of technology adoption. Columns 1 and 2 show results for cars, and columns 3 and 4 for light trucks. We find no evidence that the standards affected the direction for cars, but we find strong evidence for light trucks for periods 2, 3 and 4: there the standards caused the direction of technology adoption to shift toward fuel consumption and away from torque (and, to a lesser extent, away from weight).

To interpret the magnitudes for light truck torque, we consider a manufacturer for which the stringency is one standard deviation above the mean in the second time period (i.e., a manufacturer with a high initial fuel consumption rate compared to its standard). The size of the estimated effect implies that that manufacturer decreased torque and decreased the fuel consumption rate 5 percent (about $1 \mathrm{mpg}$ ) compared to a manufacturer with mean stringency (the estimate of 5 percent is obtained by multiplying one standard deviation of the stringency variable by the light truck coefficient for 2007-2009 in Table 4). Given that the average light truck fuel consumption rate decreased $3 \mathrm{mpg}$ during the sample period, the movement along the frontier represents a significant fuel consumption rate decrease.

Panel B of Table 4 shows results from equation (2), which focuses on the rate. The results suggest that the standards increased the rate of adoption for cars in 2010-2012 but not in the earlier periods. The truck results are consistent with the hypothesis that the standards affected the rate of adoption, as companies facing more stringent standards increased their rates of adoption 
more than other companies in the middle two time periods (see columns 3 and 4); the coefficient in the final time period is smaller and is only marginally statistically significant. In comparing the rate and direction estimates, we find them to be larger and more precise for light trucks than for cars. This difference could be explained by the fact that the standards for cars only tightened toward the end of the sample; the aggregate analysis in Section 4.2 suggested that the rate of adoption increased after 2007, but the statistical evidence in the cross-sectional estimation suggests that this response was correlated with gasoline prices, the recession, or other factors. We conclude that the rate and direction changed first for light trucks and then for cars. This timing is consistent with the timing of the change in U.S. standards. ${ }^{13}$

Interpreting the magnitudes in Panel B, we again consider the same hypothetical manufacturer facing stringency one standard deviation below the mean. For cars in 2010-2012, the rate of adoption for this manufacturer is 0.5 percentage points faster than the observed average rate of 1.4 percent per year. The light truck results for 2007-2009 suggest that the manufacturer increases the rate of adoption 1.5 percentage points above the mean of 1.5 percent per year. Thus, the estimated magnitudes imply substantial increases in the rate of adoption.

Table 5 reports the results for Europe. The key independent variable is the interaction of a dummy variable equal to one for 2008-2010 and the difference between the log emissions rate of the manufacturer and the log of the 2015 standard. As with Table 4, Panel A of Table 5 focuses on the direction of technology adoption (equation [3]) and Panel B on the rate (equation [2]). If the coefficients are negative, manufacturers with higher initial emissions rates shift direction toward lower emissions rates and raise the rate of adoption, compared to other manufacturers.

The European standards had a statistically significant effect on the direction of technology adoption away from horsepower and weight. The magnitudes of both effects are small: a one standard deviation increase in stringency causes a shift along the frontier that reduces emissions rates by 2 percent (recall that the corresponding estimate for U.S. light trucks was 5 percent). We also find that the rate of adoption increased. The magnitude implies that a one-standard-deviation increase in stringency increases the rate of adoption by 0.3 percentage points, compared to the mean rate of adoption of 2 percent. Thus, the magnitude is noticeable, but smaller than for the

\footnotetext{
13 Above we noted that the frontier estimates in equation (1) differ from those by Knittel (2011). Using the data from that paper and applying our estimation, we find that the rate of technology adoption increased for light trucks after 2003 but not for cars, which is consistent with the results reported in this paper.
} 
United States. We conclude that the European standards had a relatively small, but statistically significant, effect on the direction (horsepower and weight) as well as on the rate of technology adoption.

\subsection{Potential Omitted Variables Bias}

The fact that from 2003 to 2009 the adoption rate increased for U.S. light trucks but not for U.S. cars supports the validity of our identification strategy; confounding factors would yield spurious results only if they affected light trucks and not cars during that time period. However, gasoline prices and the recession may have differentially affected cars and light trucks; these factors represent the primary threats to the validity of equations (2) and (3). As noted, we control for these factors using triple interactions of fuel consumption rate by market segment by year. Because the reported regressions include model fixed effects, the main concern would be timevarying shocks that differentially affect vehicles in the same market segment or with the same fuel consumption rate. This section reports four approaches to assess the magnitude of any biases in this research design.

First, in the main regressions, we assume that the stringency variable is exogenous after controlling for segment-level shocks to technology adoption. While this approach controls for segment-level shocks that affect technology adoption, if segment shocks happen to be correlated with stringency we would be concerned that subsegment shocks may also be correlated with stringency. We can assess whether segment shocks are correlated with stringency by omitting the triple interactions in equations (7) and (8). Appendix Tables 3 and 4 report the same specifications as in Tables 4 and 5, without the triple interactions. The magnitudes in the appendix tables are similar to those reported in the main tables, and the qualitative conclusions are the same: there is strong evidence that the standards affected the rate and direction for U.S. light trucks, weaker evidence for the rate and direction for U.S. cars, and evidence that the European standards affected the rate and direction. These results support the assumed exogeneity of the stringency variable.

Second, the estimates would be biased if fuel prices or the recession (or other factors) reduced demand for vehicles with low fuel economy sufficiently for them to exit the market. We construct an indicator variable that is equal to one if a vehicle version exits between the current and next year. We regress the exit variable on the fuel price and on total market sales interacted with the version's fuel consumption rate. Changes in total market sales serve as a proxy for the 
effect of the recession on the aggregate market. (For the European regressions we use the emissions rate and registrations instead of fuel consumption rate and sales.) Importantly, the regressions also include the triple interaction of time period, market segment, and initial model fuel consumption rate. If either the fuel price or market sales interaction is statistically significant, we would be concerned that gasoline prices or the recession cause exit and thereby bias the results. Panel A of Table 6 reports the coefficients on the interactions. None of the interaction terms is large and statistically significant at conventional levels. A one-standarddeviation decrease in the fuel consumption rate and a one-standard-deviation increase in fuel prices or aggregate sales cause a very small (less than 2 percentage points) change in exit probability.

Third, gasoline prices or the recession could affect technology via market shares. For example, if gasoline prices raise the market share of vehicles with low fuel consumption rates, manufacturers would have greater incentive to adopt technology that reduces the fuel consumption rate of those vehicles (Acemoglu et al. 2012). Of particular concern is the possibility that fuel prices or the recession differentially affect market shares of vehicles sold by firms for which the standards are more stringent. In that case, the coefficients on the stringency interactions in Tables 4 and 5 could reflect the effects of fuel prices or the recession on technology. Panel B of Table 6 reports regressions similar to Panel A, except that (a) the dependent variable is the log of sales or registrations rather than the exit indicator and (b) the key independent variables are the interaction of stringency, time period, and either fuel consumption rate or aggregate sales. Statistically significant or large interaction coefficients would raise concerns that the other variables in equations (7) and (8) do not control adequately for the effect of fuel prices or the recession on market shares. Only the fuel price coefficient for European cars is statistically significant, and in that case the point estimate is small; a 20 percent increase in the fuel price (as occurred during the European estimation sample) affects market shares by less than 1 percent.

Finally, we control directly for gasoline prices by adding to equations (7) and (8) the interactions of gasoline prices with the stringency-time period interaction. The main results (not reported but available upon request) are unaffected. 


\section{The Opportunity Costs of Standards}

The empirical results suggest that tighter fuel economy standards increased the rate of technology adoption in both the United States and Europe and also affected the direction of technology adoption for U.S. light trucks and European cars. In that context, one could think of the opportunity cost of technology adoption as the willingness to pay for the change in characteristics other than the fuel consumption rate. In this section, we use our results to estimate the opportunity cost of tightening the standards.

We focus on opportunity costs because a full welfare analysis of the standards is beyond the scope of this paper, as it would require a dynamic model of manufacturer technology adoption, the choice of vehicle characteristics, as well as of consumer demand. Instead, we make some simplifying assumptions regarding manufacturers' responses to hypothetical standards to allow for rough estimates of opportunity costs. First, we assume that the standards do not affect vehicle prices or market shares. Klier and Linn (2012) suggest that, over periods of three to five years, it is less costly to manufacturers to adjust vehicle characteristics than to change vehicle prices and market shares; over the five-year time horizon considered here, the assumption of constant market shares may therefore not be very strong. Our second assumption is that manufacturers decrease the fuel consumption rate of all vehicles by the amount the standard requires. These assumptions allow us to focus on opportunity costs while using simulations that do not contain too many moving parts. Because of these simplifying assumptions, we treat the opportunity cost estimates as approximations.

Although we could base the simulations on the actual standards, to compare results across the United States and Europe, we use the same hypothetical standard for the two regions. Also, for comparability, we impose a fuel consumption rate standard rather than an emissions rate standard in both regions. The initial year for the simulations is 2007, which is roughly the midpoint in both the U.S. and European data sets. The analysis spans five years, 2007-2012, and we estimate the opportunity costs of decreasing the fuel consumption rate 10 percent over that time period; such an average annual decrease is greater than that required by the European standards but not as great as the requirement under the U.S. light truck standards.

We first consider a scenario in which standards are unchanged from the 2007 levels; we refer to that as the no-policy scenario. For this scenario, we set the adoption rate equal to the average frontier shift estimated in equation (2) prior to the tightening of the standards. Based on these 
estimates, we assume that all efficiency improvements in the United States are used to increase horsepower or torque, whereas efficiency improvements in Europe decrease fuel consumption rates and horsepower in equal proportions. These assumptions allow us to estimate the 2012 fuel consumption rate and horsepower of every vehicle that was sold in 2007. To simplify the analysis, we assume that the technology adoption does not affect weight.

We consider two scenarios in which the standards reduce the fuel consumption rate by 10 percent. In the first scenario, we assume that the rate of adoption is the same as in the no-policy scenario. In the second, we use the average rate of adoption estimated from equation (1) over the years 2010-2012 for U.S. cars and light trucks, and over the years 2008-2010 for European cars. We compute the movement along the frontier needed to meet the new standards.

Table 7 presents the results from these simulations. The two rows in each panel show results from the two scenarios, for low and high rates of technology adoption. The first column shows the assumed rate of technology adoption. The remaining columns show the results of the simulations, including the percentage change in horsepower relative to the no-policy case, the consumer willingness-to-pay for the lost horsepower, and the value of the fuel savings. ${ }^{14}$ The willingness to pay for the lost horsepower is computed using estimates in Klier and Linn (2012) of \$10 per horsepower per ton (in 2007 dollars). This value corresponds to the lower-end value of willingness to pay as reported in the vehicle demand literature (Whitefoot and Skerlos 2012); the opportunity costs reported in Table 7 should therefore be considered conservative estimates. $^{15}$

We focus on the high technology case because of the strong empirical evidence that the standards affected the rates of technology adoption. For the U.S. simulations, the opportunity costs — as measured by the willingness to pay for lost horsepower-are similar to the fuel savings for light trucks, but are smaller for cars. ${ }^{16}$ The costs are noticeably higher in the low-technology

\footnotetext{
14 We assume a maximum 35-year vehicle lifetime, adjusting for survival probabilities for cars and light trucks, and we use the estimated annual vehicle miles traveled by age from U.S. EPA (2012). Consumers value fuel savings at a 10 percent discount rate, which lies within the range of estimates in Busse et al. (2013). Real fuel prices are held constant at their 2007 levels over the lifetime of the vehicle, which is consistent with recent fuel price variation (Klier and Linn 2010). To maintain comparability across regions, assumptions are the same for European and U.S. consumers except for fuel prices.

${ }^{15}$ We do not allow for heterogeneous preferences for vehicle characteristics, which could affect the welfare analysis (Bento et al. 2012).

16 The estimation results in Section 4.4 showed no effect of the standards on horsepower for cars. It may seem surprising that estimated opportunity costs in Table 7 are nonzero. However, the actual standards for cars were less stringent than the standards modeled in the simulations. The simulations are performed assuming that the standards
} 
case than in the high-technology case. Because the low-technology scenario does not account for the effect of the standards on the adoption rate, the difference between the two cases demonstrates the importance of accounting for the effect of standards on the rate of adoption when estimating opportunity costs. The European opportunity costs are lower than for the United States, but are still sizeable compared to the fuel savings. The European opportunity costs are lower because, without tightened standards, the European technology adoption rate is higher than in the United States and a higher fraction of European technology adoption is devoted to reducing emissions rates.

\section{Conclusion}

Fuel economy and greenhouse gas emissions rate standards will substantially increase passenger vehicle fuel economy in the United States, in Europe, as well as in other regions. Economic theory suggests that tighter standards will increase the rate of technology adoption. Because vehicle manufacturers choose multiple vehicle characteristics in designing a vehicle and because technical tradeoffs exist across some of these characteristics, theory also suggests that the tightening of fuel economy standards will likely affect other vehicle characteristics besides fuel economy.

Consistent with these predictions, we find evidence that recently tightened fuel economy standards in the United States and Europe have increased the rate of technology adoption. We also find strong evidence that the standards affected the direction of technology adoption by reducing light truck torque in the United States and vehicle weight and horsepower in Europe. The results are robust to controlling for other, potentially confounding, influences on technology.

This paper is the first to document the effects of fuel economy standards on the rate of technology adoption. Furthermore, the previous literature has not quantified the opportunity costs of actual standards due to changes in other vehicle characteristics besides fuel economy. We use the empirical results to derive back-of-the-envelope estimates of these opportunity costs. In simulating the imposition of hypothetical standards, we find that the opportunity costs for U.S. light trucks are similar to the value of the fuel savings. The opportunity costs for U.S. and European cars are smaller in size but nonetheless economically significant.

\footnotetext{
increase the rate of adoption by the same amount as observed in response to the actual standards. More stringent standards could increase the rate of adoption further than observed, in which case the results in Table 7 would overestimate opportunity costs for U.S. cars.
} 
We leave for future work the incorporation of the opportunity costs into a fully dynamic model of the vehicles market. In such an analysis it would be possible to relax the assumption, maintained in this paper, that consumers have homogeneous willingness to pay for vehicle characteristics and that consumers fully value fuel savings. Undervaluation of fuel savings is a commonly used justification for the introduction of fuel economy standards (Allcott 2013); future work should consider the welfare and policy implications of this possibility in a dynamic context.

\section{References}

1. Acemoglu, D., P. Aghion, L. Bursztyn, and D. Hemous (2012). The Environment and Directed Technical Change. American Economic Review 102: 131-166.

2. Allcott, H. (2013). The Welfare Effects of Misperceived Product Costs: Data and Calibrations from the Automobile Market. American Economic Journal: Economic Policy 5: $1-29$.

3. Austin, D. and T. Dinan (2005). Clearing the Air: The Costs and Consequences of Higher CAFE Standards and Gasoline Prices. Journal of Environmental Economics and Management 50: 562-582.

4. Bento, A. M., S. Li, and K. Roth (2012). Is There an Energy Paradox in Fuel Economy? A Note on the Role of Consumer Heterogeneity and Sorting Bias. Economics Letters 115: 4448.

5. Busse, M., C. Knittel, and F. Zettelmeyer (2013). Are Consumers Myopic? Evidence from New and Used Car Purchases. American Economic Review 103(1): 220-256.

6. Goldberg, P. K. (1998). The Effects of the Corporate Average Fuel Efficiency Standards in the U.S. The Journal of Industrial Economics 46: 1-33.

7. Greene, D. L. (1991). Short-Run Pricing Strategies To Increase Corporate Average Fuel Economy. Economic Inquiry 29: 101-114.

8. Jacobsen, M. (2013). Evaluating U.S. Fuel Economy Standards in a Model with Producer and Household Heterogeneity. American Economic Journal: Economic Policy 5(2): 148-187.

9. Klier, T. and J. Linn (2010). The Price of Gasoline and New Vehicle Fuel Economy: Evidence from Monthly Sales Data. American Economic Journal: Economic Policy 2(3): 134-153.

10. Klier, T. and J. Linn (2012). New Vehicle Characteristics and the Cost of the Corporate Average Fuel Economy Standards. RAND Journal of Economics 43: 186-213.

11. Klier, T. and J. Linn (forthcoming). Using Vehicle Taxes To Reduce Carbon Dioxide Emissions Rates of New Passenger Vehicles: Evidence from France, Germany, and Sweden. American Economic Journal: Economic Policy.

12. Klier, T. and J. Linn (2013). Fuel Prices and New Vehicle Fuel Economy-Comparing the United States and Western Europe. Journal of Environmental Economics and Management 66: 280-300.

13. Knittel, C. (2011). Automobiles on Steroids: Product Attribute Trade-offs and Technological Progress in the Automobile Sector. The American Economic Review 107: 3368-3399. 
14. Li, S., J. Linn, and E. Spiller (2013). Evaluating "Cash-for-Clunkers": Program Effects on Auto Sales and the Environment. Journal of Environmental Economics and Management 65: 175-193.

15. Linn, J. (2008). Energy Prices and the Adoption of Energy-Saving Technology. The Economic Journal 118: 1986-2012.

16. Mazzeo, M., K. Seim, and M. Varela (2013). The Welfare Consequences of Mergers with Product Repositioning.

17. Newell, R. G., A. B. Jaffe, and R. N. Stavins (1999). The Induced Innovation Hypothesis and Energy-Saving Technological Change. Quarterly Journal of Economics 114: 941-975.

18. Popp, D. (2002). Induced Innovation and Energy Prices. American Economic Review 92: 160-180.

19. Porter, M. (1999). America’s Green Strategy. Scientific American 264: 168.

20. Roth, K. (2014). The Unintended Consequences of Uncoordinated Regulation: Evidence from the Transportation Sector.

21. Sweeting, A. (forthcoming). Dynamic Product Repositioning in Differentiated Product Markets: The Effect of Fees for Musical Performance Rights on the Commercial Radio Industry. Econometrica.

22. U.S. Department of Transportation (2006). Corporate Average Fuel Economy and CAFE Reform for MY 2008-2011 Light Trucks: Final Regulatory Impact Analysis. Washington, DC: U.S. Department of Transportation.

23. U.S. EPA and NHTSA (2012). Joint Technical Support Document: Proposed Rulemaking for 2017-2025 Light-Duty Vehicle Greenhouse Gas Emissions Standards and Corporate Average Fuel Economy Standards. Washington, DC: U.S. EPA and NHTSA.

24. Whitefoot, K., M. Fowlie, and S. Skerlos (2011). Product Design Response to Policy Intervention: Evaluating Fuel Economy Standards Using an Engineering Model of Product Design. Working paper.

25. Whitefoot, K. S. and S. J. Skerlos (2012). Design Incentives To Increase Vehicle Size Created from the U.S. Footprint-Based Fuel Economy Standards. Energy Policy 41: 402411. 
Figure 1. Fuel Consumption Rate, Emissions Rate, Horsepower, and Weight
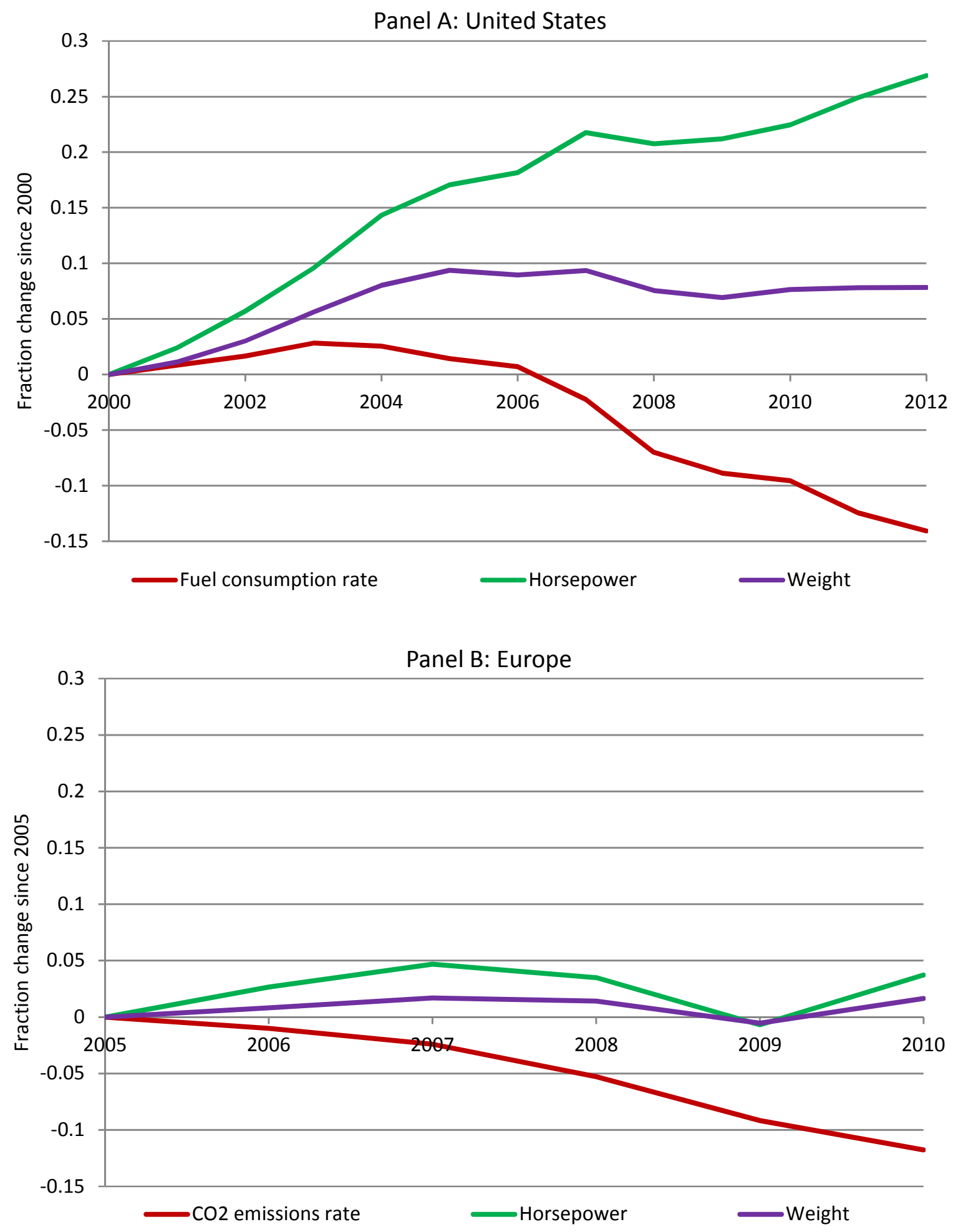

Notes: Panel A plots the fraction change in sales-weighted fuel consumption rate (Panel A), $\mathrm{CO}_{2}$ emissions rate (Panel B), weight, and power since 2000 for the United States, using the same data set as Table 1. Panel B plots fraction changes in registration-weighted fuel economy, weight, and power since 2005 for Europe, using the same data set as Table 1. 
Figure 2. Technology Adoption in the United States and Europe

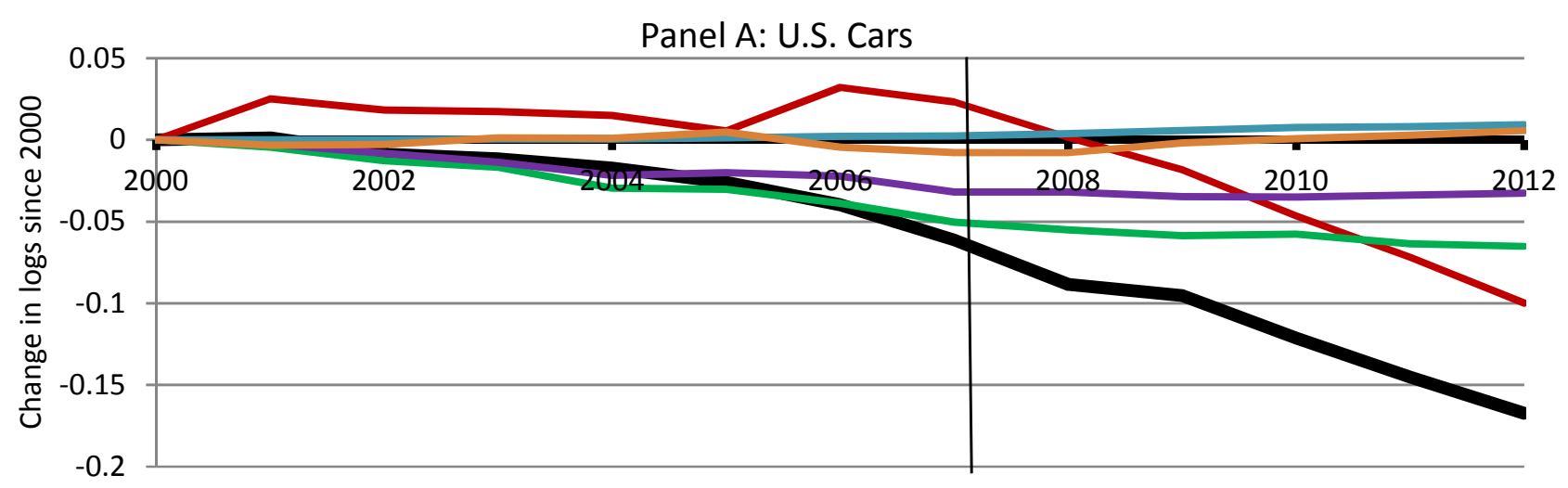

Frontier — Fuel consumption rate $\longrightarrow$ Horsepower $\longrightarrow$ Weight $\longrightarrow$ Hybrid $\longrightarrow$ Transm. type, cyl., fuel type

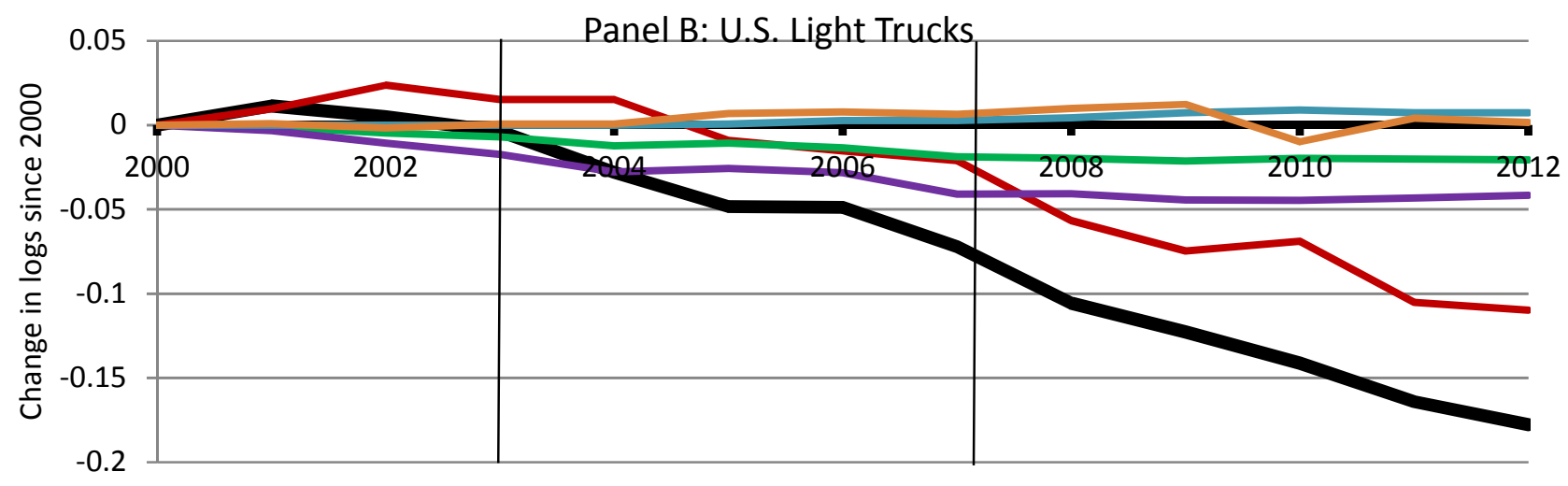

$\longrightarrow$ Frontier $\longrightarrow$ Fuel consumption rate $\longrightarrow$ Horsepower $\longrightarrow$ Weight $\longrightarrow$ Hybrid $\rightleftharpoons$ Transm. type, cyl., fuel type

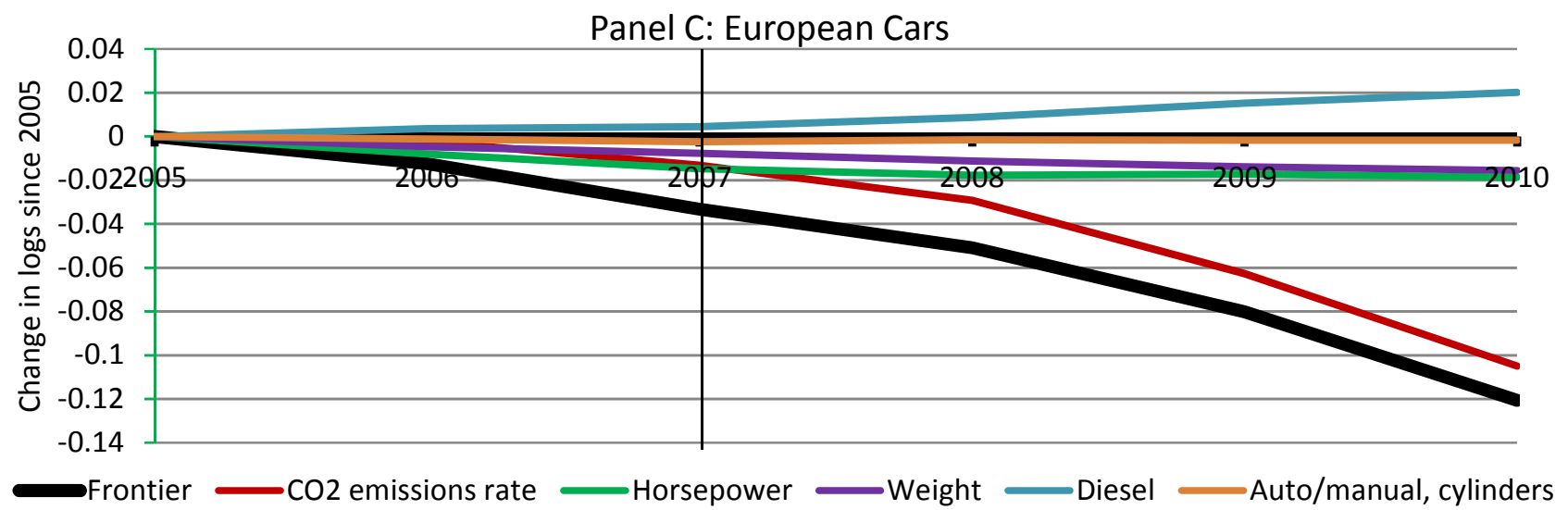

Notes : In Panel A, the frontier plots the change in redesign, model, and model-year interactions estimated in column 1 of Table 2; in Panel B, the frontier plots the interactions estimated in column 2 of Table 2; and in Panel $C$, the frontier plots the interactions estimated in column 1 of Table 3 . In Panels $A$ and $B$, fuel consumption rate is the change since 2000 in the average log fuel consumption rate across specifications. Horsepower, weight, and diesel represent the decrease in the fuel consumption rate that would have been possible if these characteristics had remained at their 2000 levels. The variables are computed using the log change in the characteristic since 2000 , multiplied by the negative of the coefficient on the corresponding characteristic from the regressions in Table 2. The curves in Panel C are constructed similarly, and represent changes since 2005. Vertical lines indicate the adoption of the higher standards. 
Figure 3. U.S. Technology Adoption by Company, Cars
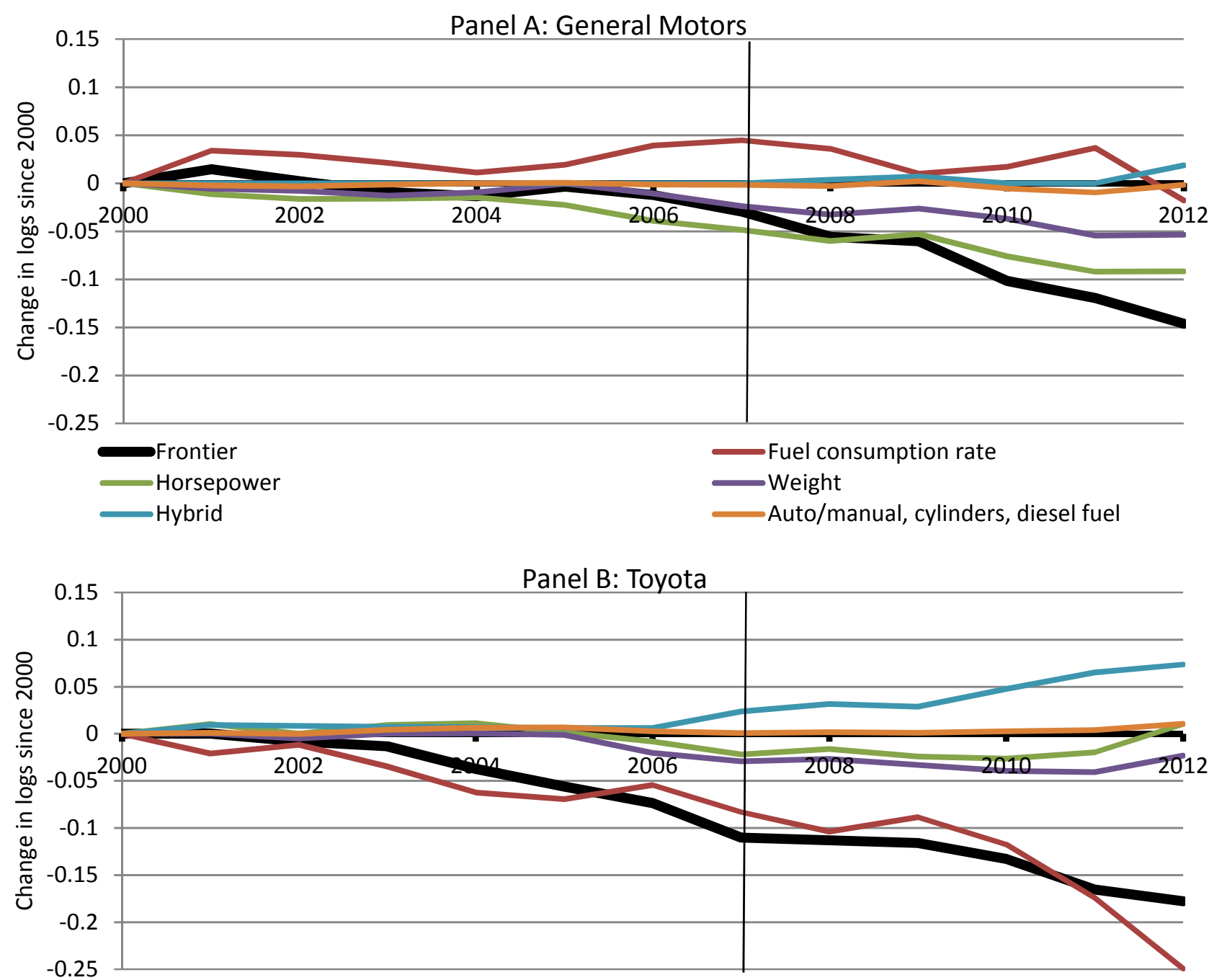

Frontier

Horsepower

Hybrid
Fuel consumption rate

Weight

Auto/manual, cylinders, diesel fuel

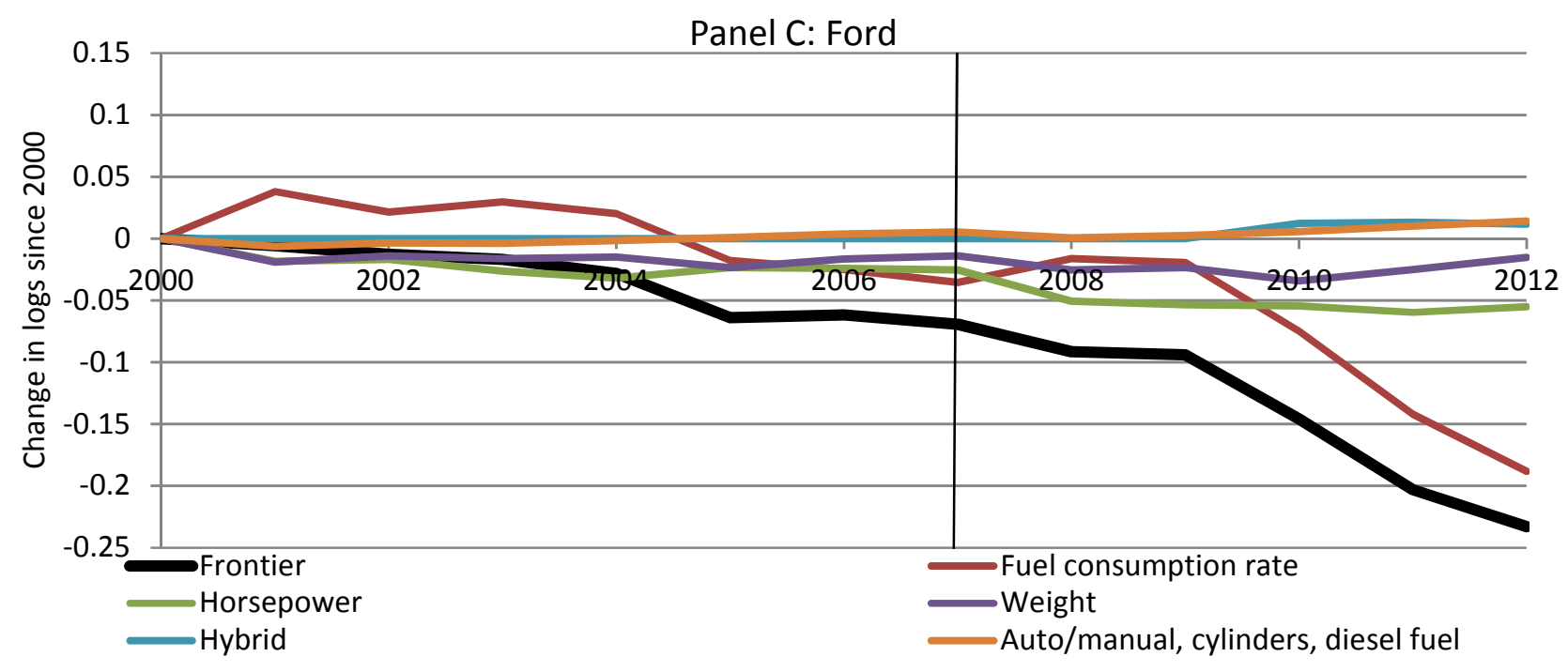



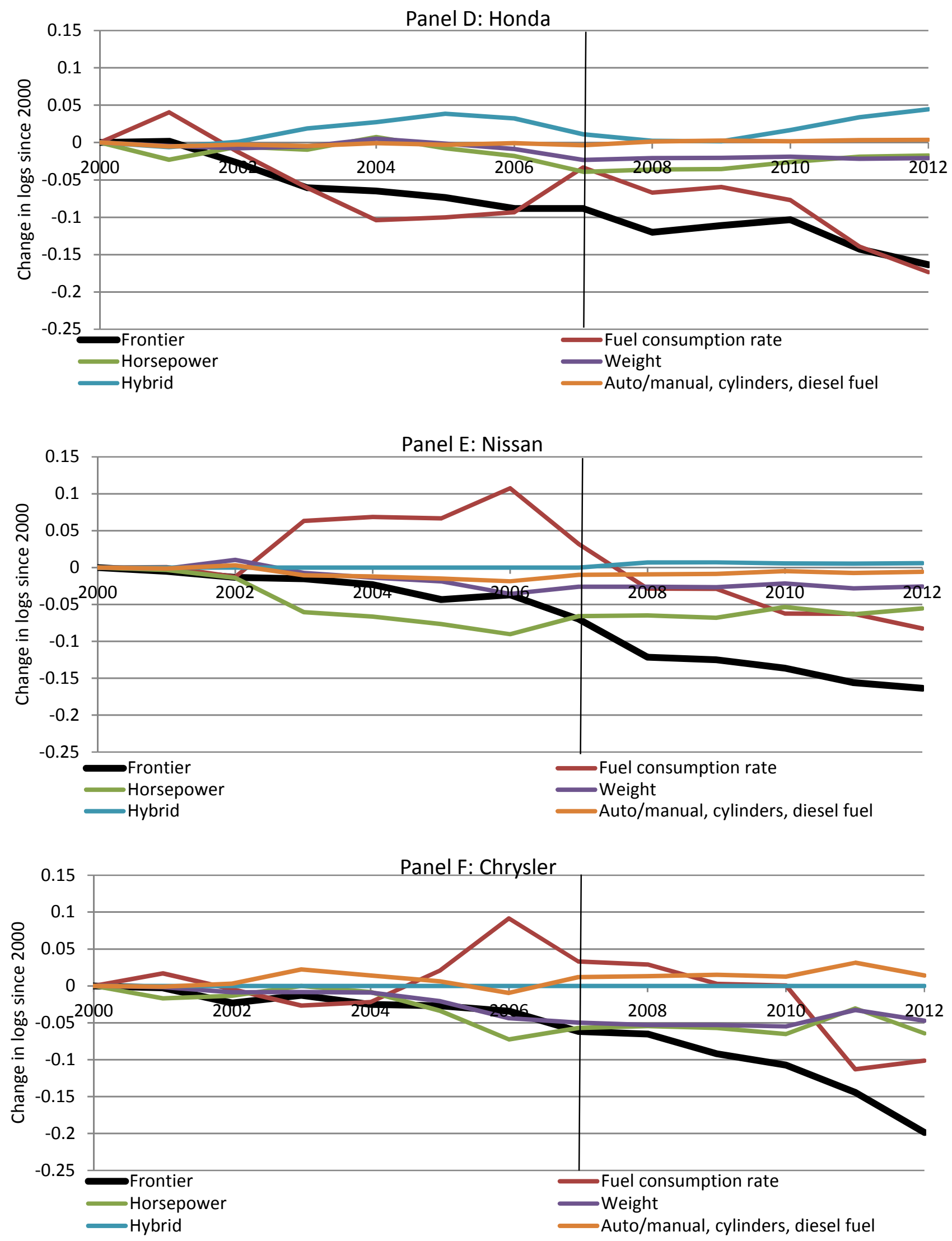
Figure 4. U.S. Technology Adoption by Company, Trucks
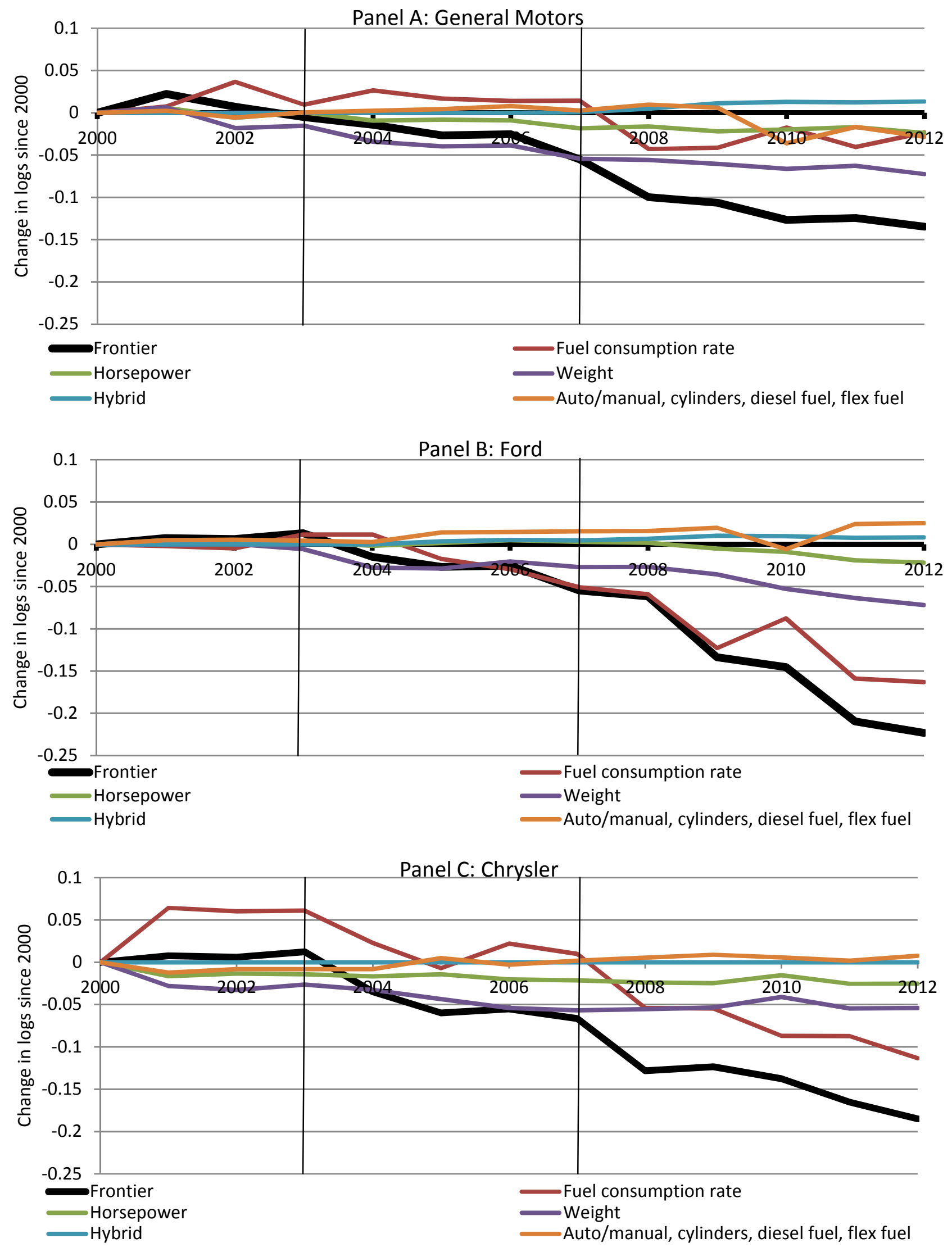

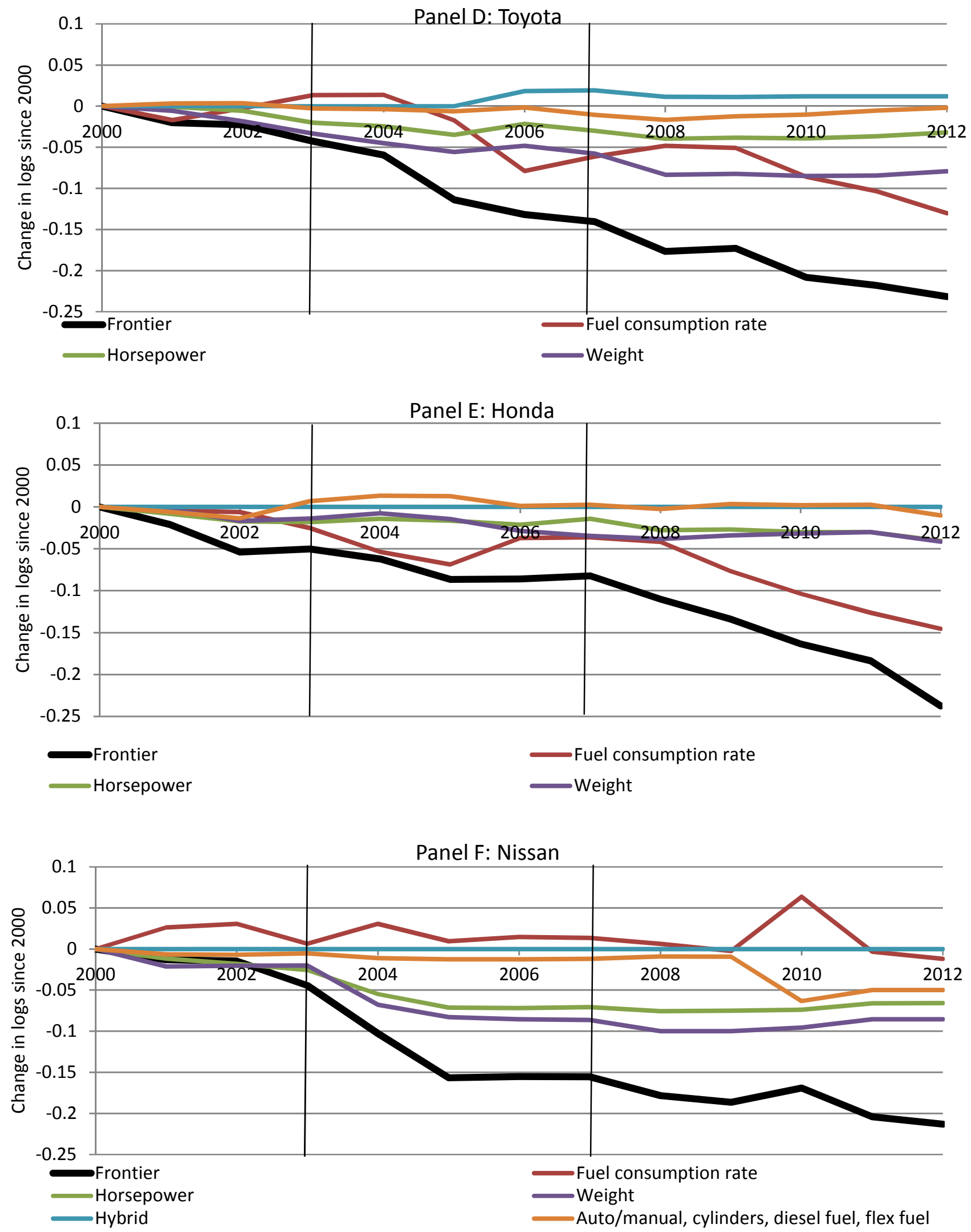
Figure 5. European Technology Adoption by Brand

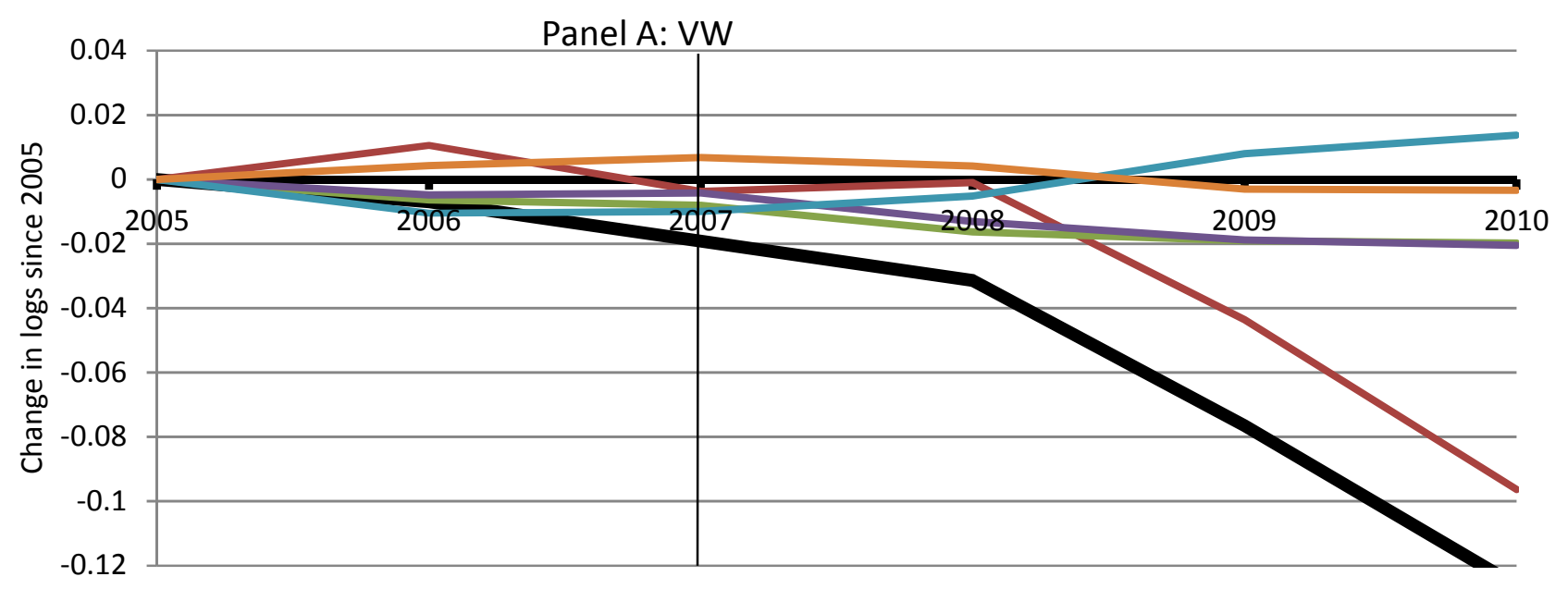

$\longrightarrow$ Frontier $\longrightarrow$ CO2 emissions rate $\longrightarrow$ Horsepower $\longrightarrow$ Weight $\longrightarrow$ Auto/manual, cylinders

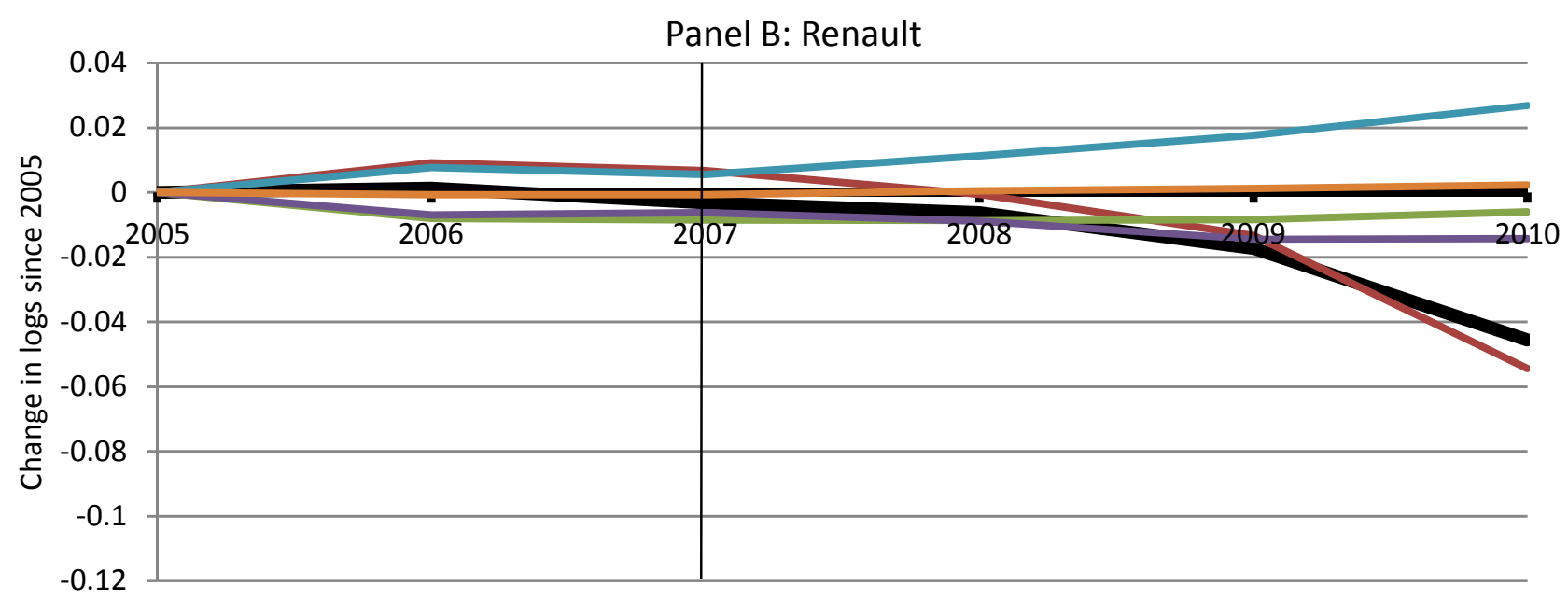

Wrontier $\longrightarrow$ CO2 emissions rate $\longrightarrow$ Horsepower $\longrightarrow$ Weight $\longrightarrow$ Auto/manual, cylinders

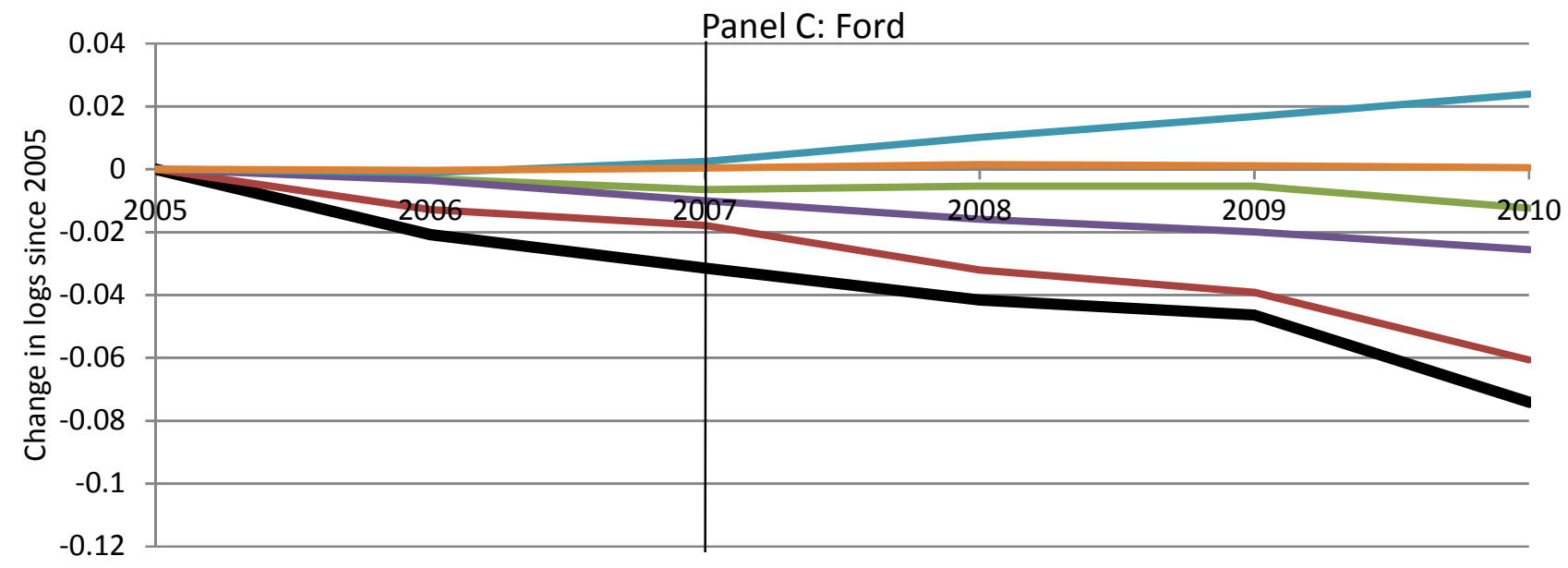

$\longrightarrow$ Frontier $\longrightarrow$ CO2 emissions rate $\longrightarrow$ Horsepower $\longrightarrow$ Weight $\longrightarrow$ Auto/manual, cylinders 

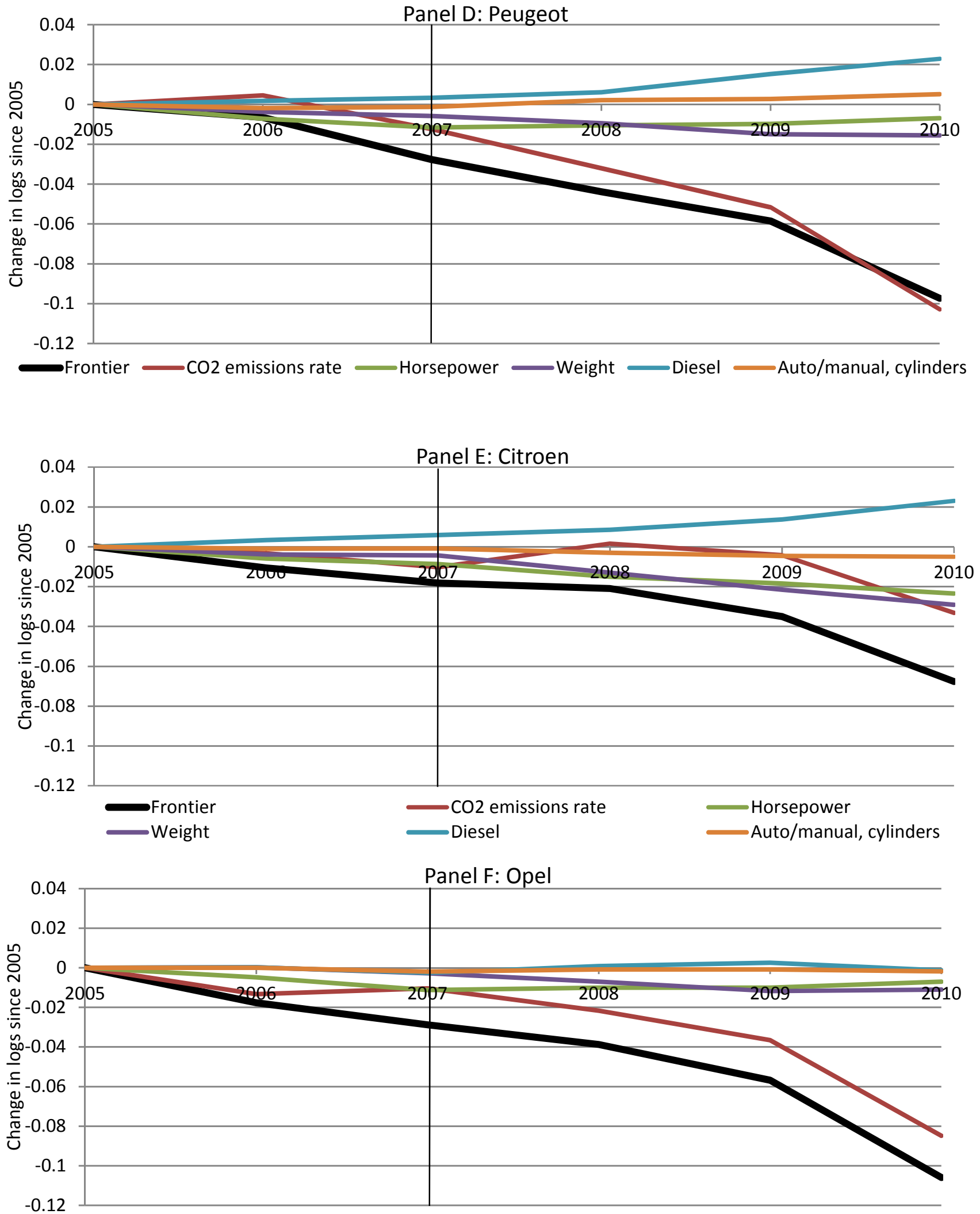

Frontier $\longrightarrow$ CO2 emissions rate - Horsepower $\longrightarrow$ Weight $\longrightarrow$ Diesel $\longrightarrow$ Auto/manual, cylinders 


\begin{tabular}{|c|c|c|c|c|}
\hline & \multicolumn{2}{|c|}{ United States } & \multicolumn{2}{|c|}{ Europe } \\
\hline & $\underline{2005}$ & $\underline{2010}$ & $\underline{2005}$ & $\underline{2010}$ \\
\hline $\begin{array}{l}\text { Sales or } \\
\text { registrations }\end{array}$ & $\begin{array}{c}12,586.85 \\
(11,894.34)\end{array}$ & $\begin{array}{c}6,855.51 \\
(8,051.22)\end{array}$ & $\begin{array}{c}268.19 \\
(829.14)\end{array}$ & $\begin{array}{c}203.79 \\
(628.92)\end{array}$ \\
\hline $\begin{array}{l}\text { Fuel economy } \\
\text { (mpg) }\end{array}$ & $\begin{array}{l}25.21 \\
(6.10)\end{array}$ & $\begin{array}{l}26.78 \\
(7.01)\end{array}$ & $\begin{array}{l}34.47 \\
(8.94)\end{array}$ & $\begin{array}{l}38.16 \\
(9.27)\end{array}$ \\
\hline \multicolumn{5}{|l|}{$\begin{array}{l}\text { Fuel } \\
\text { consumption }\end{array}$} \\
\hline $\begin{array}{l}\text { rate (gallons } \\
\text { per } 100 \text { miles) }\end{array}$ & $\begin{array}{c}4.16 \\
(0.84)\end{array}$ & $\begin{array}{c}3.97 \\
(0.99)\end{array}$ & $\begin{array}{c}3.11 \\
(0.86)\end{array}$ & $\begin{array}{c}2.79 \\
(0.76)\end{array}$ \\
\hline Horsepower & $\begin{array}{l}228.21 \\
(64.64)\end{array}$ & $\begin{array}{l}258.12 \\
(77.63)\end{array}$ & $\begin{array}{l}134.44 \\
(56.01)\end{array}$ & $\begin{array}{l}150.01 \\
(68.34)\end{array}$ \\
\hline Weight (tons) & $\begin{array}{c}1.99 \\
(0.41)\end{array}$ & $\begin{array}{c}2.09 \\
(0.46)\end{array}$ & $\begin{array}{c}2.09 \\
(0.37)\end{array}$ & $\begin{array}{c}2.21 \\
(0.42)\end{array}$ \\
\hline $\begin{array}{l}\text { Number of } \\
\text { obserations }\end{array}$ & 1,352 & 1,546 & 46,521 & 47,884 \\
\hline
\end{tabular}

Notes: The table reports the means of the indicated variables, with standard deviations in parentheses, for model-years 2005 and 2010. The United States data set includes observations by model version from 2000 to 2011, and the European data set includes observations by model version for 2005 to 2010. For the United States, weight is the curb weight; for Europe, weight is the gross vehicle weight. See text for details on the construction of the data sets. 


\section{Table 2. United States: Tradeoffs between Fuel Consumption Rate and Other Vehicle Characteristics}

\section{Dependent variable: log fuel consumption rate}

$\begin{array}{lcc}\text { Log horsepower or } & 0.237 & 0.156 \\ \text { torque } & (0.015) & (0.016) \\ \text { Log weight } & 0.336 & 0.430 \\ & (0.044) & (0.047) \\ \text { Diesel fuel } & -0.344 & -0.269 \\ & (0.019) & (0.020) \\ \text { Hybrid } & -0.260 & -0.293 \\ & (0.020) & (0.010) \\ \text { Flex fuel } & & 0.282 \\ \text { Manual } & & (0.014) \\ \text { transmission } & 0.002 & 0.005 \\ \text { Number of } & (0.005) & (0.004) \\ \text { observations } & 6,856 & 12,208 \\ R^{2} & & \\ \text { Sample includes } & 0.957 & 0.937 \\ & \text { Cars } & \text { Light trucks }\end{array}$

Interactions of redesign, model, and model- Interactions of redesign, model, and modelRegression includes year, and fixed effects for number of year, and fixed effects for number of cylinders and number of doors cylinders and number of doors

Notes: The table reports coefficient estimates, with standard errors in parentheses, clustered by redesign, model, and model-year. Observations are by model version and model-year, and the dependent variable is the log fuel consumption rate. Besides the reported variables, the regressions include the variables indicated at the bottom of the table. The sample includes cars in column 1 and light trucks in column 2. Column 1 uses the log of horsepower as an independent variable, and column 2 uses the log of torque. 
Table 3. Europe: Tradeoffs between $\mathrm{CO}_{2}$ Emissions Rate and Other Vehicle

(1)

(2)

Dependent variable: $\log \mathrm{CO}_{2}$ emissions rate

Log horsepower

0.190

0.158

(0.002)

(0.002)

Log weight

0.307

0.241

(0.007)

Diesel fuel

$-0.174$

$-0.172$

(0.001)

Manual transmission

$-0.071$

$-0.076$

(0.001)

Number of

observations

276,376

276,376

$\mathrm{R}^{2}$

0.916

0.944

Regression includes

Number of cylinders and interactions of redesign, model, and model-year
Number of cylinders and interactions of redesign, model-trim, and model-year

Notes : The table reports coefficient estimates, with standard errors in parentheses, clustered by redesign, model trim, and model-year. Observations are by model version and model-year, and the dependent variable is log of the $\mathrm{CO}_{2}$ emissions rate. Besides the reported variables, the regressions include the variables indicated at the bottom of the table. A model trim includes all specifications with the same model, body type, number of doors, driven wheels, and trim level. 


\begin{tabular}{|c|c|c|c|c|}
\hline & (1) & (2) & (3) & (4) \\
\hline & \multicolumn{4}{|c|}{ Panel A: direction } \\
\hline $\begin{array}{l}\text { Dependent } \\
\text { variable }\end{array}$ & $\begin{array}{c}\text { Log (fuel cons rate / } \\
\text { horsepower) }\end{array}$ & $\begin{array}{c}\text { Log (fuel cons rate / } \\
\text { weight) }\end{array}$ & $\begin{array}{c}\text { Log (fuel cons rate / } \\
\text { torque) }\end{array}$ & $\begin{array}{l}\text { Log (fuel cons rate / } \\
\text { weight) }\end{array}$ \\
\hline Stringency $\mathrm{X}$ & 0.131 & 0.070 & -0.824 & -0.260 \\
\hline 2003-2006 & $(0.078)$ & (0.059) & $(0.136)$ & $(0.085)$ \\
\hline Stringency $\mathrm{X}$ & 0.084 & 0.022 & -0.939 & -0.308 \\
\hline 2007-2009 & $(0.090)$ & $(0.065)$ & $(0.148)$ & (0.094) \\
\hline Stringency $X$ & -0.029 & 0.057 & -0.749 & -0.094 \\
\hline 2010-2012 & $(0.093)$ & $(0.071)$ & $(0.157)$ & $(0.106)$ \\
\hline $\begin{array}{l}\text { Number of } \\
\text { observations }\end{array}$ & 6,856 & 6,856 & 11,966 & 11,966 \\
\hline \multirow[t]{2}{*}{$\mathrm{R}^{2}$} & 0.783 & 0.623 & 0.625 & 0.633 \\
\hline & \multicolumn{4}{|c|}{$\underline{\text { Panel B: rate }}$} \\
\hline Stringency $\mathrm{X}$ & 0.017 & 0.006 & -0.226 & -0.241 \\
\hline 2003-2006 & $(0.040)$ & $(0.040)$ & $(0.063)$ & $(0.065)$ \\
\hline Stringency $X$ & -0.024 & -0.056 & -0.269 & -0.261 \\
\hline 2007-2009 & $(0.047)$ & $(0.046)$ & $(0.065)$ & $(0.066)$ \\
\hline Stringency $X$ & -0.091 & -0.101 & -0.142 & -0.123 \\
\hline 2010-2012 & $(0.051)$ & $(0.050)$ & $(0.067)$ & $(0.068)$ \\
\hline $\begin{array}{l}\text { Number of } \\
\text { observations }\end{array}$ & 1,749 & 1,749 & 1,425 & 1,425 \\
\hline$R^{2}$ & 0.768 & 0.766 & 0.847 & 0.838 \\
\hline Sample includes & Cars & Cars & Light trucks & Light trucks \\
\hline $\begin{array}{l}\text { Frontier } \\
\text { estimated by }\end{array}$ & Entire market & Market segment & Entire market & Market segment \\
\hline \multicolumn{5}{|c|}{$\begin{array}{l}\text { Notes : The table reports coefficient estimates, with standard errors in parentheses, clustered by redesign, } \\
\text { model, and model-year. Observations are by model version and model-year in Panel A and by redesign, model, } \\
\text { and model-year in Panel B. Regressions in columns } 1 \text { and } 2 \text { include cars, and regressions in columns } 3 \text { and } 4 \\
\text { include light trucks. In Panel A, the dependent variable is the log of the ratio of fuel consumption rate to } \\
\text { horsepower in column 1, the log of the ratio of fuel consumption rate to weight in columns } 2 \text { and } 4 \text {, and the log } \\
\text { of the ratio of fuel consumption rate to torque in column } 3 \text {. The dependent variable in Panel B is the estimated } \\
\text { redesign-model-year interaction from equation (7). Columns } 1 \text { and } 3 \text { use the estimated redesign-model-year } \\
\text { interactions from Table } 2 \text { and columns } 2 \text { and } 4 \text { use estimates from Table } 3 \text {. Stringency is the difference between } \\
\text { the log sales-weighted standard for the corresponding company and vehicle type and the log sales-weighted } \\
\text { fuel economy in } 2000 \text {. The calculation uses the } 2016 \text { standards. All regressions include model fixed effects and } \\
\text { triple interactions between model-year, market segment, and log fuel consumption rate of the model in } 2000 \text {, } \\
\text { along with all associated main effects and double interaction terms. }\end{array}$} \\
\hline
\end{tabular}




\section{Table 5. Effect of European Emissions Rate Standards on Direction and Rate of Technology Adoption}

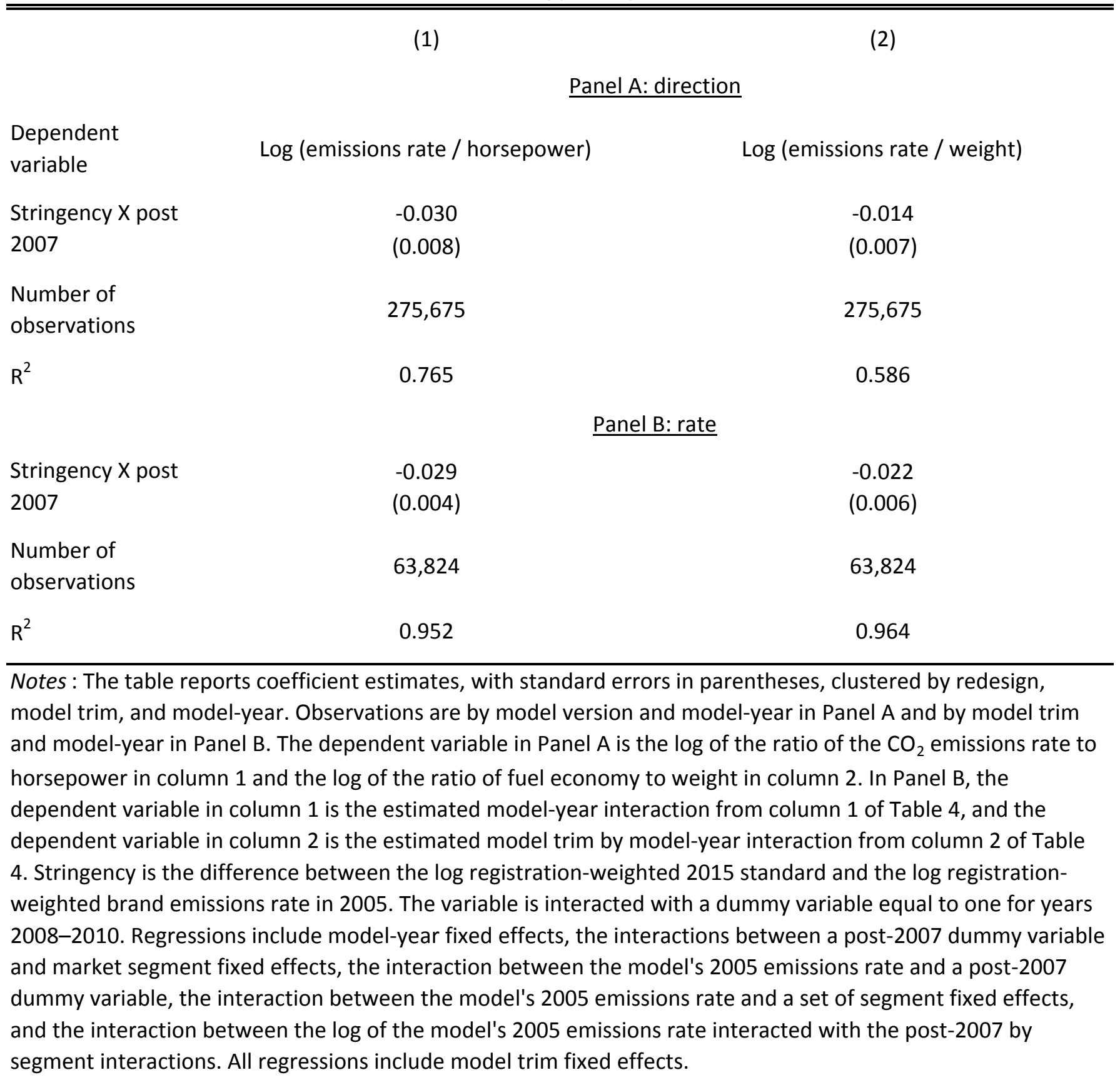




\section{Table 6. Potential Omitted Variables Bias: Fuel Prices and the Recession}

Log fuel cons rate / emissions
rate X log fuel price
Log fuel cons rate / emissions
rate X log aggregate sales /
Number of observations
$\mathrm{R}^{2}$

Sample includes

Stringency X 2003-2006 X log gas

price

Stringency X 2007-2009 X log gas

price

Stringency $\times 2010-2012 \times$ log gas

price

Stringency X 2003-2006 X log

aggregate sales

Stringency X 2007-2009 X log

aggregate sales

Stringency X 2010-2012 X log

aggregate sales

Stringency $X$ post $2007 X \log$ fuel

price

Stringency $X$ post $2007 X \log$

aggregate registrations

Number of observations

$\mathrm{R}^{2}$

Sample includes
(1)

(2)

(3)

Panel A: exit

0.104

(0.219)

$-0.103$

(0.324)

5,850

0.162

U.S. cars

$-2.705$

(3.583)

$-6.253$

(8.877)

$-21.801$

(68.811)

35.060

(45.445)

3.173

(5.884)

$-1.067$

(8.949)
0.409

(0.257)

0.299

(0.349)

5,524

0.237

U.S. light trucks

Panel B: sales and registrations

0.850
$(3.093)$
-7.406
$(6.565)$
-3.653
$(9.256)$
-10.022
$(43.094)$
7.151
$(4.557)$
1.257
$(3.178)$

0.040

(0.036)

0.017

(0.109)

228,492

0.009

European cars

Notes : Standard errors are in parentheses, clustered by redesign, model, and model-year in Panel A and by model and model-year in Panel B. Observations are by model version and model-year in Panel A and by model and model-year in Panel $B$. The dependent variable in Panel $A$ is an indicator equal to one if the vehicle exits between the current and next years. The dependent variable in Panel $B$ is the log sales in columns 1 and 2 and the log registrations in column 3 . Log fuel cons rate $X \log$ fuel price is the interaction between log fuel consumption rate and the log of the fuel price. Log fuel cons rate $X$ aggregate sales is the interaction between the vehicle's log fuel consumption rate and the log of the total annual sales in the market. In Panel, A columns 1 and 2 include these variables along with the main effects of the interaction terms. In Panel A, column 3 uses the same main effects and interaction terms, except that the emissions rate replaces the fuel consumption rate and registrations replaces sales. Instead of these variables, Panel B includes the interactions of stringency, time period, and gas price or aggregate sales. Stringency and time periods are defined as in Tables 6 and 7. All regressions include triple interactions of year, market segment, and initial fuel consumption rate, along with lower-order main effects and interactions, as in Tables 6 and 7. 
Table 7. Effects on Consumer Welfare of a 10 Percent Fuel Consumption Rate Decrease

(1)

Frontier shift

(2007-2012)

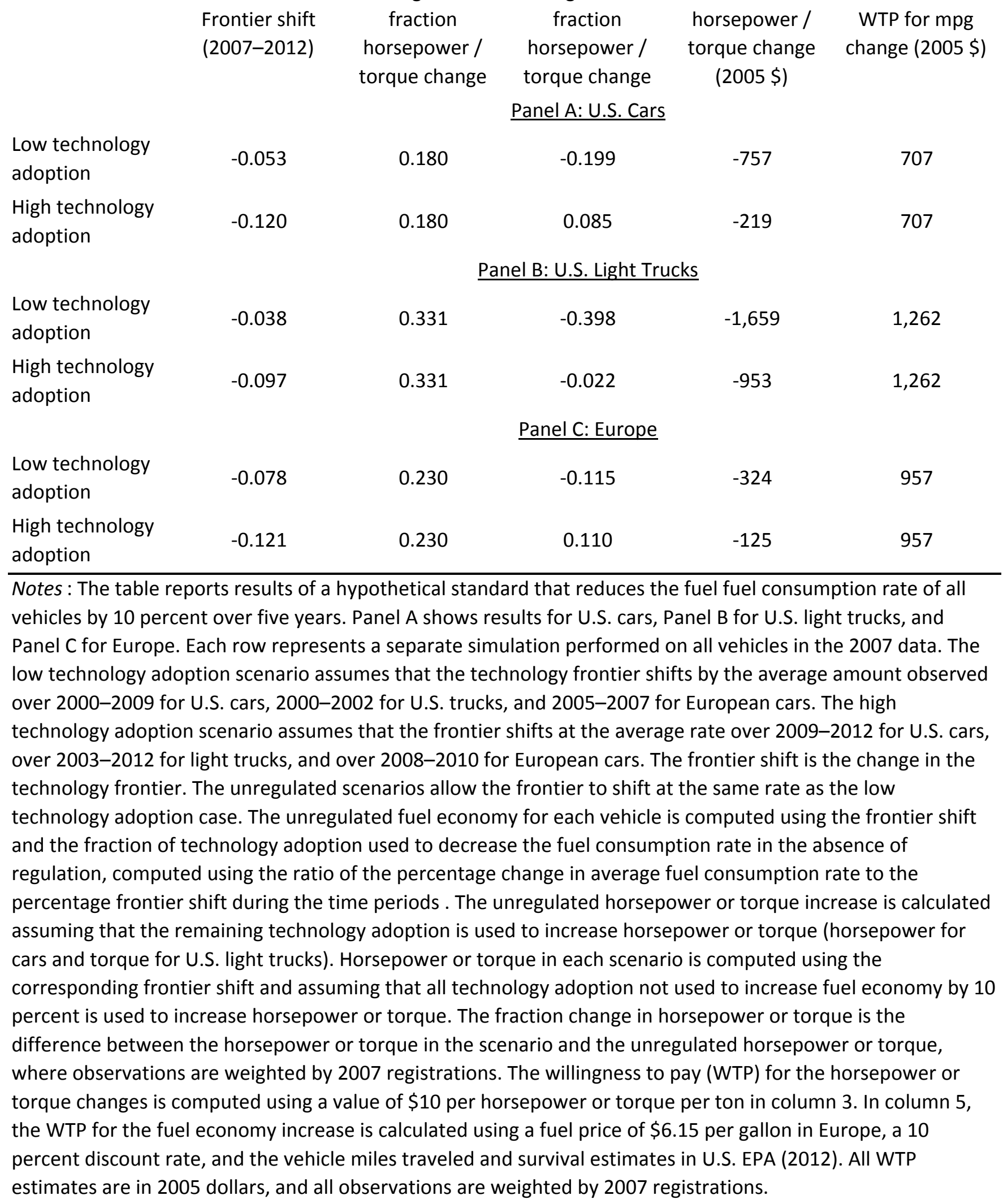

(4)

(5)

(2)

(3)

WTP for

horsepower / WTP for mpg

torque change change (2005\$)

$(2005 \$)$

\begin{tabular}{|c|c|c|c|c|c|}
\hline & $\begin{array}{l}\text { Frontier shift } \\
(2007-2012)\end{array}$ & $\begin{array}{c}\text { fraction } \\
\text { horsepower / } \\
\text { torque change }\end{array}$ & $\begin{array}{c}\text { fraction } \\
\text { horsepower / } \\
\text { torque change } \\
\text { Panel A: U.S. Cars }\end{array}$ & $\begin{array}{c}\text { horsepower / } \\
\text { torque change } \\
(2005 \$)\end{array}$ & $\begin{array}{l}\text { WTP for mpg } \\
\text { change (2005 \$) }\end{array}$ \\
\hline $\begin{array}{l}\text { Low technology } \\
\text { adoption }\end{array}$ & -0.053 & 0.180 & -0.199 & -757 & 707 \\
\hline \multirow[t]{2}{*}{$\begin{array}{l}\text { High technology } \\
\text { adoption }\end{array}$} & -0.120 & 0.180 & 0.085 & -219 & 707 \\
\hline & \multicolumn{5}{|c|}{ Panel B: U.S. Light Trucks } \\
\hline $\begin{array}{l}\text { Low technology } \\
\text { adoption }\end{array}$ & -0.038 & 0.331 & -0.398 & $-1,659$ & 1,262 \\
\hline \multirow[t]{2}{*}{$\begin{array}{l}\text { High technology } \\
\text { adoption }\end{array}$} & -0.097 & 0.331 & -0.022 & -953 & 1,262 \\
\hline & \multicolumn{5}{|c|}{ Panel C: Europe } \\
\hline $\begin{array}{l}\text { Low technology } \\
\text { adoption }\end{array}$ & -0.078 & 0.230 & -0.115 & -324 & 957 \\
\hline $\begin{array}{l}\text { High technology } \\
\text { adoption }\end{array}$ & -0.121 & 0.230 & 0.110 & -125 & 957 \\
\hline $\begin{array}{l}\text { Notes : The table } \\
\text { vehicles by } 10 \text { per } \\
\text { Panel C for Europ } \\
\text { low technology ac } \\
\text { over 2000-2009 } \mathrm{f} \\
\text { technology adopt } \\
\text { over } 2003-2012 \mathrm{f} \\
\text { technology fronti } \\
\text { technology adopt } \\
\text { and the fraction o } \\
\text { regulation, compc } \\
\text { percentage fronti } \\
\text { assuming that the } \\
\text { cars and torque fo } \\
\text { corresponding fro } \\
\text { percent is used to } \\
\text { difference betwe } \\
\text { where observatio } \\
\text { torque changes is } \\
\text { the WTP for the f } \\
\text { percent discount }\end{array}$ & $\begin{array}{l}\text { trts results of } \\
\text { t over five yea } \\
\text { ach row repres } \\
\text { ion scenario a } \\
\text { J.S. cars, 2000- } \\
\text { scenario assun } \\
\text { ght trucks, anc } \\
\text { he unregulate } \\
\text { case. The unre } \\
\text { chnology adop } \\
\text { using the rati } \\
\text { hift during the } \\
\text { naining techno } \\
\text { S. light trucks } \\
\text { r shift and ass } \\
\text { rease horsepo } \\
\text { ne horsepowe } \\
\text { re weighted b } \\
\text { nputed using a } \\
\text { economy incre } \\
\text {, and the vehic }\end{array}$ & $\begin{array}{l}\text { pothetical stanc } \\
\text { Panel A shows re } \\
\text { s a separate sim } \\
\text { mes that the tec } \\
2 \text { for U.S. truck } \\
\text { that the frontie } \\
\text { er 2008-2010 fc } \\
\text { anarios allow th } \\
\text { ated fuel econor } \\
\text { used to decrea } \\
\text { the percentage } \\
\text { e periods. The } \\
\text { y adoption is us } \\
\text { orsepower or to } \\
\text { ing that all techr } \\
\text { or torque. The } \\
\text { torque in the sc } \\
07 \text { registrations } \\
\text { lue of } \$ 10 \text { per hc } \\
\text { is calculated usi } \\
\text { niles traveled ar }\end{array}$ & $\begin{array}{l}\text { ard that reduces th } \\
\text { sults for U.S. cars, } \\
\text { ulation performed } \\
\text { hnology frontier sh } \\
\text {, and } 2005-2007 \mathrm{f} \\
\text { shifts at the avera } \\
\text { r European cars. Th } \\
\text { e frontier to shift } \\
\text { ny for each vehicle } \\
\text { se the fuel consum } \\
\text { change in average } \\
\text { inregulated horsep } \\
\text { d to increase hors } \\
\text { que in each scenar } \\
\text { ology adoption no } \\
\text { raction change in } \\
\text { enario and the unr } \\
\text { The willingness to } \\
\text { rsepower or torqu } \\
\text { ng a fuel price of } \$ \\
\text { d survival estimate }\end{array}$ & $\begin{array}{l}\text { fuel fuel consun } \\
\text { anel B for U.S. lig } \\
\text { n all vehicles in t } \\
\text { ts by the averag } \\
r \text { European cars. } \\
\text { e rate over 2009. } \\
\text { e frontier shift is } \\
\text { the same rate as } \\
\text { s computed using } \\
\text { tion rate in the a } \\
\text { uel consumption } \\
\text { wer or torque in } \\
\text { power or torque } \\
\text { o is computed us } \\
\text { used to increase } \\
\text { brsepower or tor } \\
\text { gulated horsepov } \\
\text { pay (WTP) for the } \\
\text { per ton in colum } \\
15 \text { per gallon in } \\
\text { in U.S. EPA (201 }\end{array}$ & $\begin{array}{l}\text { ption rate of all } \\
\text { tt trucks, and } \\
\text { e } 2007 \text { data. The } \\
\text { amount observed } \\
\text { he high } \\
2012 \text { for U.S. cars, } \\
\text { he change in the } \\
\text { the low } \\
\text { the frontier shift } \\
\text { sence of } \\
\text { ate to the } \\
\text { rease is calculated } \\
\text { horsepower for } \\
\text { g the } \\
\text { uel economy by } 10 \\
\text { ue is the } \\
\text { er or torque, } \\
\text { horsepower or } \\
3 . \text { In column } 5 \text {, } \\
\text { urope, a } 10 \\
\text { ). All WTP }\end{array}$ \\
\hline
\end{tabular}

Panel A: U.S. Cars 
Appendix Table 1. Tradeoffs by Segment: United States

(1)

(2)

(3)

(4)

(5)

(6)

(7)

Dependent variable: log fuel consumption rate

\begin{tabular}{|c|c|c|c|c|c|c|c|}
\hline $\begin{array}{l}\text { Log horsepower or } \\
\text { torque }\end{array}$ & $\begin{array}{c}0.245 \\
(0.028)\end{array}$ & $\begin{array}{c}0.188 \\
(0.028)\end{array}$ & $\begin{array}{c}0.200 \\
(0.016)\end{array}$ & $\begin{array}{c}0.165 \\
(0.022)\end{array}$ & $\begin{array}{c}0.154 \\
(0.026)\end{array}$ & $\begin{array}{c}0.183 \\
(0.051)\end{array}$ & $\begin{array}{c}0.122 \\
(0.021)\end{array}$ \\
\hline Log weight & $\begin{array}{c}0.654 \\
(0.107)\end{array}$ & $\begin{array}{c}0.186 \\
(0.060)\end{array}$ & $\begin{array}{c}0.275 \\
(0.053)\end{array}$ & $\begin{array}{c}0.571 \\
(0.105)\end{array}$ & $\begin{array}{c}0.587 \\
(0.035)\end{array}$ & $\begin{array}{c}0.358 \\
(0.051)\end{array}$ & $\begin{array}{c}0.399 \\
(0.058)\end{array}$ \\
\hline Diesel fuel & $\begin{array}{l}-0.375 \\
(0.017)\end{array}$ & $\begin{array}{l}-0.201 \\
(0.028)\end{array}$ & $\begin{array}{l}-0.309 \\
(0.022)\end{array}$ & $\begin{array}{l}-0.287 \\
(0.018)\end{array}$ & $\begin{array}{l}-0.228 \\
(0.019)\end{array}$ & & \\
\hline Flex fuel & & & & $\begin{array}{c}0.352 \\
(0.003)\end{array}$ & $\begin{array}{c}0.290 \\
(0.011)\end{array}$ & $\begin{array}{c}0.225 \\
(0.003)\end{array}$ & $\begin{array}{c}0.280 \\
(0.017)\end{array}$ \\
\hline $\begin{array}{l}\text { Manual } \\
\text { transmission }\end{array}$ & $\begin{array}{c}0.002 \\
(0.010)\end{array}$ & $\begin{array}{l}-0.006 \\
(0.006)\end{array}$ & $\begin{array}{c}0.012 \\
(0.007)\end{array}$ & $\begin{array}{l}-0.008 \\
(0.008)\end{array}$ & $\begin{array}{l}-0.003 \\
(0.005)\end{array}$ & & $\begin{array}{c}0.004 \\
(0.004)\end{array}$ \\
\hline Sample includes & Small cars & Medium cars & Large/luxury cars & Crossovers & $\begin{array}{l}\text { Sport utility } \\
\text { vehicles }\end{array}$ & Vans & Pickups \\
\hline
\end{tabular}

Notes : The table reports coefficient estimates, with standard errors in parentheses, clustered by model and model-year. Columns 1-3 report similar regressions to those reported in column 1 of Table 2, except that the sample is restricted to included observations from the market segment indicated at the bottom of the table; likewise, columns 4-7 correspond to column 2 in Table 2. 


\section{Appendix Table 2. Tradeoffs by Segment: Europe}

(1)
(2)

(3)
(5)

(6)

Dependent variable: $\log \mathrm{CO}_{2}$ emissions rate

\begin{tabular}{|c|c|c|c|c|c|c|}
\hline Log horsepower & $\begin{array}{c}0.163 \\
(0.009)\end{array}$ & $\begin{array}{c}0.182 \\
(0.003)\end{array}$ & $\begin{array}{c}0.252 \\
(0.002)\end{array}$ & $\begin{array}{c}0.145 \\
(0.003)\end{array}$ & $\begin{array}{c}0.061 \\
(0.005)\end{array}$ & $\begin{array}{c}0.021 \\
(0.019)\end{array}$ \\
\hline Log weight & $\begin{array}{c}0.246 \\
(0.040)\end{array}$ & $\begin{array}{c}0.207 \\
(0.018)\end{array}$ & $\begin{array}{c}0.263 \\
(0.012)\end{array}$ & $\begin{array}{c}0.360 \\
(0.014)\end{array}$ & $\begin{array}{c}0.375 \\
(0.016)\end{array}$ & $\begin{array}{c}0.206 \\
(0.035)\end{array}$ \\
\hline Diesel fuel & $\begin{array}{l}-0.140 \\
(0.004)\end{array}$ & $\begin{array}{l}-0.197 \\
(0.001)\end{array}$ & $\begin{array}{l}-0.173 \\
(0.001)\end{array}$ & $\begin{array}{l}-0.174 \\
(0.001)\end{array}$ & $\begin{array}{l}-0.163 \\
(0.002)\end{array}$ & $\begin{array}{c}-0.134 \\
(0.005)\end{array}$ \\
\hline $\begin{array}{l}\text { Manual } \\
\text { transmission }\end{array}$ & $\begin{array}{l}-0.058 \\
(0.004)\end{array}$ & $\begin{array}{l}-0.065 \\
(0.001)\end{array}$ & $\begin{array}{l}-0.076 \\
(0.001)\end{array}$ & $\begin{array}{l}-0.076 \\
(0.001)\end{array}$ & $\begin{array}{l}-0.059 \\
(0.001)\end{array}$ & $\begin{array}{l}-0.009 \\
(0.009)\end{array}$ \\
\hline $\begin{array}{l}\text { Number of } \\
\text { observations }\end{array}$ & 8,263 & 47,425 & 91,430 & 90,206 & 35,170 & 3,882 \\
\hline $\mathrm{R}^{2}$ & 0.812 & 0.820 & 0.796 & 0.868 & 0.909 & 0.892 \\
\hline Sample includes & Mini & Small & Lower medium & Medium & Upper medium & Large \\
\hline
\end{tabular}

Notes : The table reports coefficient estimates, with standard errors in parentheses, clustered by model and model-year. Each column reports a similar regression to column 1 of Table 3 except that the sample is restricted to included observations from the market segment indicated at the bottom of the table. 


\begin{tabular}{|c|c|c|c|c|}
\hline \multicolumn{5}{|c|}{$\begin{array}{r}\text { Appendix Table 3. Effect of U.S. Standards on Direction an } \\
\text { Adoption, Omitting Other Controls }\end{array}$} \\
\hline & (1) & (2) & (3) & (4) \\
\hline & \multicolumn{4}{|c|}{ Panel A: direction } \\
\hline $\begin{array}{l}\text { Dependent } \\
\text { variable }\end{array}$ & $\begin{array}{l}\text { Log (fuel cons rate / } \\
\text { horsepower) }\end{array}$ & $\begin{array}{l}\text { Log (fuel cons rate / } \\
\text { weight) }\end{array}$ & $\begin{array}{l}\text { Log (fuel cons rate / } \\
\quad \text { torque) }\end{array}$ & $\begin{array}{l}\text { Log (fuel cons rate / } \\
\text { weight) }\end{array}$ \\
\hline Stringency $\mathrm{X}$ & 0.047 & 0.032 & -0.646 & -0.320 \\
\hline 2003-2006 & $(0.068)$ & $(0.052)$ & $(0.120)$ & $(0.070)$ \\
\hline Stringency $\mathrm{X}$ & 0.003 & 0.052 & -0.878 & -0.441 \\
\hline 2007-2009 & $(0.073)$ & $(0.055)$ & $(0.134)$ & $(0.078)$ \\
\hline Stringency $X$ & -0.083 & 0.049 & -0.714 & -0.242 \\
\hline 2010-2012 & $(0.077)$ & $(0.066)$ & $(0.142)$ & $(0.092)$ \\
\hline $\begin{array}{l}\text { Number of } \\
\text { observations }\end{array}$ & 6,856 & 6,856 & 11,966 & 11,966 \\
\hline \multirow[t]{2}{*}{$\mathrm{R}^{2}$} & 0.781 & 0.615 & 0.616 & 0.622 \\
\hline & \multicolumn{4}{|c|}{$\underline{\text { Panel B: rate }}$} \\
\hline Stringency $\mathrm{X}$ & -0.034 & -0.053 & -0.270 & -0.276 \\
\hline 2003-2006 & $(0.046)$ & (0.049) & $(0.056)$ & $(0.061)$ \\
\hline Stringency $X$ & -0.046 & -0.051 & -0.371 & -0.337 \\
\hline 2007-2009 & $(0.050)$ & $(0.051)$ & $(0.055)$ & $(0.062)$ \\
\hline Stringency $\mathrm{X}$ & -0.140 & -0.091 & -0.281 & -0.225 \\
\hline 2010-2012 & $(0.064)$ & $(0.062)$ & $(0.056)$ & $(0.063)$ \\
\hline $\begin{array}{l}\text { Number of } \\
\text { observations }\end{array}$ & 1,749 & 1,749 & 1,425 & 1,425 \\
\hline $\mathrm{R}^{2}$ & 0.753 & 0.754 & 0.829 & 0.821 \\
\hline Sample includes & Cars & Cars & Light trucks & Light trucks \\
\hline $\begin{array}{l}\text { Frontier } \\
\text { estimated by }\end{array}$ & Entire market & Market segment & Entire market & Market segment \\
\hline
\end{tabular}

Notes: The table reports coefficient estimates, with standard errors in parentheses, clustered by redesign, model, and model-year. Regressions are the same as in Table 4 except that the independent variables include only the reported variables, model-year fixed effects, and model fixed effects. 


\begin{tabular}{|c|c|c|}
\hline \multicolumn{3}{|c|}{$\begin{array}{r}\text { Appendix Table 4. Effect of European Emissions Rate Standards on Di } \\
\text { Technology Adoption, Omitting Other Controls } \\
\end{array}$} \\
\hline & (1) & $(2)$ \\
\hline \multicolumn{3}{|c|}{$\underline{\text { Panel A: direction }}$} \\
\hline $\begin{array}{l}\text { Dependent } \\
\text { variable }\end{array}$ & Log (emissions rate / horsepower) & Log (emissions rate / weight) \\
\hline Stringency $X$ post & -0.076 & -0.046 \\
\hline 2007 & $(0.007)$ & $(0.006)$ \\
\hline $\begin{array}{l}\text { Number of } \\
\text { observations }\end{array}$ & 275,675 & 275,675 \\
\hline $\mathrm{R}^{2}$ & 0.764 & 0.585 \\
\hline \multicolumn{3}{|c|}{ Panel B: rate } \\
\hline Stringency $X$ post & -0.028 & -0.022 \\
\hline 2007 & $(0.003)$ & $(0.005)$ \\
\hline $\begin{array}{l}\text { Number of } \\
\text { observations }\end{array}$ & 63,824 & 63,824 \\
\hline $\mathrm{R}^{2}$ & 0.950 & 0.963 \\
\hline $\begin{array}{l}\text { Frontier } \\
\text { estimated by }\end{array}$ & Entire market & Market segment \\
\hline
\end{tabular}

Notes : The table reports coefficient estimates, with standard errors in parentheses, clustered by redesign, model, and model-year. Regressions are the same as in Table 5 except that the independent variables include the reported variables, model-year fixed effects, and model trim fixed effects. 


\section{Working Paper Series}

A series of research studies on regional economic issues relating to the Seventh Federal Reserve District, and on financial and economic topics.

Corporate Average Fuel Economy Standards and the Market for New Vehicles

WP-11-01

Thomas Klier and Joshua Linn

The Role of Securitization in Mortgage Renegotiation

WP-11-02

Sumit Agarwal, Gene Amromin, Itzhak Ben-David, Souphala Chomsisengphet, and Douglas D. Evanoff

Market-Based Loss Mitigation Practices for Troubled Mortgages

Following the Financial Crisis

Sumit Agarwal, Gene Amromin, Itzhak Ben-David, Souphala Chomsisengphet, and Douglas D. Evanoff

Federal Reserve Policies and Financial Market Conditions During the Crisis

WP-11-04

Scott A. Brave and Hesna Genay

The Financial Labor Supply Accelerator

WP-11-05

Jeffrey R. Campbell and Zvi Hercowitz

Survival and long-run dynamics with heterogeneous beliefs under recursive preferences Jaroslav Borovička

WP-11-06

A Leverage-based Model of Speculative Bubbles (Revised)

WP-11-07

Gadi Barlevy

Estimation of Panel Data Regression Models with Two-Sided Censoring or Truncation Sule Alan, Bo E. Honoré, Luojia Hu, and Søren Leth-Petersen

Fertility Transitions Along the Extensive and Intensive Margins

Daniel Aaronson, Fabian Lange, and Bhashkar Mazumder

Black-White Differences in Intergenerational Economic Mobility in the US

WP-11-10

Bhashkar Mazumder

Can Standard Preferences Explain the Prices of Out-of-the-Money S\&P 500 Put Options?

Luca Benzoni, Pierre Collin-Dufresne, and Robert S. Goldstein

WP-11-11

Business Networks, Production Chains, and Productivity:

A Theory of Input-Output Architecture

WP-11-12

Ezra Oberfield

Equilibrium Bank Runs Revisited

WP-11-13

Ed Nosal

Are Covered Bonds a Substitute for Mortgage-Backed Securities?

WP-11-14

Santiago Carbó-Valverde, Richard J. Rosen, and Francisco Rodríguez-Fernández

WP-11-15

The Cost of Banking Panics in an Age before "Too Big to Fail"

Benjamin Chabot 


\section{Working Paper Series (continued)}

Import Protection, Business Cycles, and Exchange Rates:

Evidence from the Great Recession

WP-11-16

Chad P. Bown and Meredith A. Crowley

Examining Macroeconomic Models through the Lens of Asset Pricing

WP-12-01

Jaroslav Borovička and Lars Peter Hansen

The Chicago Fed DSGE Model

WP-12-02

Scott A. Brave, Jeffrey R. Campbell, Jonas D.M. Fisher, and Alejandro Justiniano

Macroeconomic Effects of Federal Reserve Forward Guidance

WP-12-03

Jeffrey R. Campbell, Charles L. Evans, Jonas D.M. Fisher, and Alejandro Justiniano

Modeling Credit Contagion via the Updating of Fragile Beliefs

WP-12-04

Luca Benzoni, Pierre Collin-Dufresne, Robert S. Goldstein, and Jean Helwege

Signaling Effects of Monetary Policy

WP-12-05

Leonardo Melosi

Empirical Research on Sovereign Debt and Default

WP-12-06

Michael Tomz and Mark L. J. Wright

Credit Risk and Disaster Risk

WP-12-07

François Gourio

From the Horse's Mouth: How do Investor Expectations of Risk and Return

Vary with Economic Conditions?

WP-12-08

Gene Amromin and Steven A. Sharpe

Using Vehicle Taxes To Reduce Carbon Dioxide Emissions Rates of

New Passenger Vehicles: Evidence from France, Germany, and Sweden

WP-12-09

Thomas Klier and Joshua Linn

Spending Responses to State Sales Tax Holidays

WP-12-10

Sumit Agarwal and Leslie McGranahan

Micro Data and Macro Technology

WP-12-11

Ezra Oberfield and Devesh Raval

The Effect of Disability Insurance Receipt on Labor Supply: A Dynamic Analysis

WP-12-12

Eric French and Jae Song

Medicaid Insurance in Old Age

WP-12-13

Mariacristina De Nardi, Eric French, and John Bailey Jones

WP-12-14

Fetal Origins and Parental Responses

Douglas Almond and Bhashkar Mazumder 


\section{Working Paper Series (continued)}

Repos, Fire Sales, and Bankruptcy Policy

WP-12-15

Gaetano Antinolfi, Francesca Carapella, Charles Kahn, Antoine Martin,

David Mills, and Ed Nosal

Speculative Runs on Interest Rate Pegs

The Frictionless Case

WP-12-16

Marco Bassetto and Christopher Phelan

Institutions, the Cost of Capital, and Long-Run Economic Growth:

Evidence from the 19th Century Capital Market

WP-12-17

Ron Alquist and Ben Chabot

Emerging Economies, Trade Policy, and Macroeconomic Shocks

WP-12-18

Chad P. Bown and Meredith A. Crowley

The Urban Density Premium across Establishments

WP-13-01

R. Jason Faberman and Matthew Freedman

Why Do Borrowers Make Mortgage Refinancing Mistakes?

WP-13-02

Sumit Agarwal, Richard J. Rosen, and Vincent Yao

Bank Panics, Government Guarantees, and the Long-Run Size of the Financial Sector:

Evidence from Free-Banking America

WP-13-03

Benjamin Chabot and Charles C. Moul

Fiscal Consequences of Paying Interest on Reserves

WP-13-04

Marco Bassetto and Todd Messer

Properties of the Vacancy Statistic in the Discrete Circle Covering Problem

WP-13-05

Gadi Barlevy and H. N. Nagaraja

Credit Crunches and Credit Allocation in a Model of Entrepreneurship

WP-13-06

Marco Bassetto, Marco Cagetti, and Mariacristina De Nardi

Financial Incentives and Educational Investment:

The Impact of Performance-Based Scholarships on Student Time Use

WP-13-07

Lisa Barrow and Cecilia Elena Rouse

The Global Welfare Impact of China: Trade Integration and Technological Change

Julian di Giovanni, Andrei A. Levchenko, and Jing Zhang

WP-13-08

Structural Change in an Open Economy

WP-13-09

Timothy Uy, Kei-Mu Yi, and Jing Zhang

The Global Labor Market Impact of Emerging Giants: a Quantitative Assessment

WP-13-10

Andrei A. Levchenko and Jing Zhang 


\section{Working Paper Series (continued)}

Size-Dependent Regulations, Firm Size Distribution, and Reallocation

WP-13-11

François Gourio and Nicolas Roys

Modeling the Evolution of Expectations and Uncertainty in General Equilibrium

WP-13-12

Francesco Bianchi and Leonardo Melosi

Rushing into American Dream? House Prices, Timing of Homeownership, and Adjustment of Consumer Credit

Sumit Agarwal, Luojia Hu, and Xing Huang

WP-13-13

The Earned Income Tax Credit and Food Consumption Patterns

WP-13-14

Leslie McGranahan and Diane W. Schanzenbach

Agglomeration in the European automobile supplier industry

WP-13-15

Thomas Klier and Dan McMillen

Human Capital and Long-Run Labor Income Risk

WP-13-16

Luca Benzoni and Olena Chyruk

The Effects of the Saving and Banking Glut on the U.S. Economy

WP-13-17

Alejandro Justiniano, Giorgio E. Primiceri, and Andrea Tambalotti

A Portfolio-Balance Approach to the Nominal Term Structure

WP-13-18

Thomas B. King

Gross Migration, Housing and Urban Population Dynamics

WP-13-19

Morris A. Davis, Jonas D.M. Fisher, and Marcelo Veracierto

Very Simple Markov-Perfect Industry Dynamics

WP-13-20

Jaap H. Abbring, Jeffrey R. Campbell, Jan Tilly, and Nan Yang

Bubbles and Leverage: A Simple and Unified Approach

WP-13-21

Robert Barsky and Theodore Bogusz

The scarcity value of Treasury collateral:

Repo market effects of security-specific supply and demand factors

WP-13-22

Stefania D'Amico, Roger Fan, and Yuriy Kitsul

Gambling for Dollars: Strategic Hedge Fund Manager Investment

WP-13-23

Dan Bernhardt and Ed Nosal

Cash-in-the-Market Pricing in a Model with Money and

Over-the-Counter Financial Markets

WP-13-24

Fabrizio Mattesini and Ed Nosal

An Interview with Neil Wallace

WP-13-25

David Altig and Ed Nosal 


\section{Working Paper Series (continued)}

Firm Dynamics and the Minimum Wage: A Putty-Clay Approach

WP-13-26

Daniel Aaronson, Eric French, and Isaac Sorkin

Policy Intervention in Debt Renegotiation:

Evidence from the Home Affordable Modification Program

WP-13-27

Sumit Agarwal, Gene Amromin, Itzhak Ben-David, Souphala Chomsisengphet, Tomasz Piskorski, and Amit Seru

The Effects of the Massachusetts Health Reform on Financial Distress

WP-14-01

Bhashkar Mazumder and Sarah Miller

Can Intangible Capital Explain Cyclical Movements in the Labor Wedge?

WP-14-02

François Gourio and Leena Rudanko

Early Public Banks

William Roberds and François R. Velde

WP-14-03

Mandatory Disclosure and Financial Contagion

WP-14-04

Fernando Alvarez and Gadi Barlevy

The Stock of External Sovereign Debt: Can We Take the Data at 'Face Value'?

WP-14-05

Daniel A. Dias, Christine Richmond, and Mark L. J. Wright

Interpreting the Pari Passu Clause in Sovereign Bond Contracts:

It's All Hebrew (and Aramaic) to Me

WP-14-06

Mark L. J. Wright

AIG in Hindsight

WP-14-07

Robert McDonald and Anna Paulson

WP-14-08

On the Structural Interpretation of the Smets-Wouters "Risk Premium" Shock

Jonas D.M. Fisher

Human Capital Risk, Contract Enforcement, and the Macroeconomy

WP-14-09

Tom Krebs, Moritz Kuhn, and Mark L. J. Wright

Adverse Selection, Risk Sharing and Business Cycles

WP-14-10

Marcelo Veracierto

Core and 'Crust': Consumer Prices and the Term Structure of Interest Rates

WP-14-11

Andrea Ajello, Luca Benzoni, and Olena Chyruk

The Evolution of Comparative Advantage: Measurement and Implications

WP-14-12 Andrei A. Levchenko and Jing Zhang 


\section{Working Paper Series (continued)}

Saving Europe?: The Unpleasant Arithmetic of Fiscal Austerity in Integrated Economies Enrique G. Mendoza, Linda L. Tesar, and Jing Zhang

WP-14-13

Liquidity Traps and Monetary Policy: Managing a Credit Crunch

WP-14-14

Francisco Buera and Juan Pablo Nicolini

Quantitative Easing in Joseph’s Egypt with Keynesian Producers

WP-14-15

Jeffrey R. Campbell

Constrained Discretion and Central Bank Transparency

WP-14-16

Francesco Bianchi and Leonardo Melosi

Escaping the Great Recession

WP-14-17

Francesco Bianchi and Leonardo Melosi

WP-14-18

More on Middlemen: Equilibrium Entry and Efficiency in Intermediated Markets

Ed Nosal, Yuet-Yee Wong, and Randall Wright

Preventing Bank Runs

WP-14-19

David Andolfatto, Ed Nosal, and Bruno Sultanum

The Impact of Chicago's Small High School Initiative

WP-14-20

Lisa Barrow, Diane Whitmore Schanzenbach, and Amy Claessens

Credit Supply and the Housing Boom

WP-14-21

Alejandro Justiniano, Giorgio E. Primiceri, and Andrea Tambalotti

WP-14-22

The Effect of Vehicle Fuel Economy Standards on Technology Adoption Thomas Klier and Joshua Linn 